\title{
K-12 ESL Writing Instruction: A Review of Research on Pedagogical Challenges and Strategies
}

\author{
SUBRATA BHOWMIK \\ University of Calgary \\ MARCIA KIM \\ University of Calgary
}

\begin{abstract}
Writing is an important early literacy skill for English as a Second Language (ESL) students' academic success, underlining the importance of effective ESL writing instruction at the K-12 level. However, there is little empirical research on ESL writing instruction in school settings. The goal of this systematic literature review is to examine the extant empirical evidence of the challenges teachers encounter in teaching ESL writing and the strategies that can be adopted to help teachers overcome the challenges. Our search yielded 49 peer-reviewed journal articles and book chapters published between 2010-2019. A content analysis (Stan, 2009) of these materials indicated that teachers encounter the following challenges in teaching K-12 ESL writing: (a) lack of pre-service training in ESL writing, (b) lack of writing pedagogy skills, (c) lack of time, (d) lack of professional development opportunities, (e) standardized tests, and (f) unique L1 influences on L2 students' text production. The content analysis also revealed the following strategies that can be recommended for addressing these challenges: (a) incorporating an ESL writing course into teacher education programs, (b) creating opportunities for writing pedagogy support by mentor teachers and researchers, (c) incorporating integrated skills development in the writing classroom, (d) providing students with opportunities to write more, (e) adopting explicit writing instruction, and (f) creating professional development opportunities for teachers. Based on our findings, we discuss implications and recommendations for ESL writing instruction in K-12 schools.
\end{abstract}

Keywords

ESL writing, K-12 education, literacy, teacher education, writing instruction

\section{Introduction}

Scholars have noted that ESL writing in K-12 contexts has generally been an understudied area (e.g., Hirvela \& Belcher, 2007; Matsuda \& De Pew, 2002; OrtmeierHooper \& Enright, 2011). As a result, there has been little empirical research on how ESL writing is taught, what challenges teachers encounter, and what strategies can be adopted to overcome these challenges. Hirvela and Belcher (2007), for example, note that "we have tended to focus more of our attention on the needs of those learning to write [in a second language (L2)] rather than of those learning to teach writing" (p. 128). This underscores the importance of an investigation of ESL writing instruction in K-12 settings at a time when the ESL student population is increasing "in English-dominant educational contexts" 
(Ortmeier-Hooper \& Enright, 2011, p. 167). A case in point is the Canadian K-12 classroom, where ESL learners constitute a high percentage of the student population today. Roessingh (2018) notes that in 2017, the Vancouver School Board in British Columbia recorded $60 \%$ of its students as English Language Learners (ELLs). In Alberta, there were 110,000 ELLs in late 2017 (CBC News, 2018). In the Calgary Board of Education there were more than 26,000 ESL students, and in the Calgary Catholic School District there were nearly 15,000 ESL students (Calgary Board of Education, 2017). In Ontario, the Durham District School Board reported that the number of ELLs doubled between Fall 2014 and Fall 2018 (Follert, 2019).

Different jurisdictions within Canada use different terminologies (e.g., ESL, EAL learners or ELLs) to describe K-12 students whose first language is not English. In British Columbia, ELL stands for English Language Learning, and immigrant and refugee students whose first language is not English are referred to as English as an Additional Language (EAL) learners (The Government of British Columbia, 2020). In Alberta, on the other hand, both ESL and ELL are used interchangeably to describe these students (Calgary Board of Education, 2017). In Ontario, these students are referred to as English Language Learners (ELLs) who might have been born in or outside Canada but use a language other than English as their first language (Ontario Education, 2007). In this paper, we have used ELL and ESL synonymously.

In spite of the variation of terminologies used to describe this K-12 student population, a common reference point is that these students' first language is not English, and they need English language support to be successful in school. Unfortunately, research shows that they are falling behind in provincial achievement tests when compared to their native-English-speaking counterparts (e.g., Pavlov, 2015; Roessingh \& Douglas, 2012; Roessingh \& Elgie, 2009). High school drop-out rates and academic failure of these students are also among the highest (e.g., Roessingh, 2004; Sweet et al., 2019; Toohey \& Derwing, 2008).

In light of the above, effective early literacy education is an area that deserves special attention for inquiry, since early literacy development is a prerequisite for students' academic success. Roessingh and Elgie (2009), for example, found that the literacy gaps between native-English-speaking students and ELLs widen in middle school, resulting in their less precise and nuanced communication abilities (e.g., story retelling). The researchers noted that effective literacy instruction was connected to ELLs' vocabulary development, a pre-requisite for their successful academic writing abilities. But literacy instruction for ELLs is a complex undertaking because of these students' unique needs (Roessingh, 2004, 2008). Most of these children arrive in English-dominant countries such as Canada from different parts of the world at various ages or are born to immigrant parents. In addition to adjusting to a foreign country, they have to contend with disparate language and cultural experiences, both inside and outside of the classroom (Roessingh, 2008; Roessingh \& Elgie, 2009). Guo et al.'s (2019) research indicates that students with a limited first language (L1) literacy background tend to struggle when studying in an L2 setting. As well, scholars have underlined the significant impact of culture on literacy learning in an L2 context. Many of these children receive little academic support at home as their parents have limited English language proficiency and familiarity with literacy practices in schools and the L2 culture (e.g., Roessingh \& Kover, 2002). As a result, 
teachers encounter various challenges when teaching these children. Sound pedagogical practices that are informed by research and sensitive to the needs of ELLs are essential for making education both effective and meaningful.

This underlines the importance of an examination of the current literacy education practices of ESL teachers. Of particular significance is ESL writing instruction because writing generally receives the least attention of the four language skills (i.e., reading, listening and speaking being the other skills) (Larsen, 2013, 2016). Although it is widely acknowledged that writing is an important skill that ELLs need for academic success (Huie \& Yahya, 2003; Schulz, 2009), there is little or no systematic research on ESL writing instruction that could inform K-12 ESL writing pedagogy in the classroom. The current paper is an attempt to address this gap in the way of reviewing the extant empirical research on this topic and gaining an understanding about the challenges teachers encounter in teaching ESL writing and the strategies to overcome these challenges.

Thus, this review is guided by the following research questions (RQs):

RQ1: What challenges do teachers encounter in teaching ESL writing in K-12 contexts?

RQ2: What strategies can be adopted to help teachers overcome these challenges?

\section{Methods}

In our review, we adapted the method used by Williams and Lowrance-Faulhaber (2018). We chose this method because Williams and Lowrance-Faulhaber's study was: (a) a systematic literature review similar to ours, (b) on L2 writing of young bilingual children, (c) a very recent work, and (d) published in the flagship journal of L2 writing, i.e., the Journal of Second Language Writing. As part of our research process, we searched different databases through our university library system. Most notable of these databases were: ERIC (EBSCOhost), Research Starters-Education, Academic Search Complete (EBSCO), Education Research Complete, Linguistics and Language Behavior Abstracts and JSTOR. As well, we employed various combinations of keyword searches for our topic. The key words we used are as follows: writing in ESL, bilingual ESL writing, ESL writing, $K-12$ writing, biliteracy in ESL writing, $K-12$ multilingual $^{1}$ writing, ELL writing instruction, multilingual writing, K-12 ESL writing, ESL writing literacy, multilingual writing instruction, ELL writing, ESL literacy development, teaching ESL writing, teaching ELL writing, ELL student writing, ESL children writing and ELL writing literacy. Once relevant articles or book chapters were identified, we also searched their references to find additional sources.

\section{Inclusion criteria}

At the beginning of our research, we set clear inclusion criteria for our review (Petticrew \& Roberts, 2006). We determined the following inclusion criteria for each study: (a) that it was an empirical study; (b) that it was published in a peer reviewed journal or book between 2010-2019; and (c) that the findings had implications for some aspect of writing instruction in K-12 settings, involving students and/or teachers studying and/or teaching in an ESL and/or ESL-bilingual setting. The rationale behind using these inclusion

\footnotetext{
${ }^{1}$ In L2 writing literature, the term "multilingual writing” is often used synonymously with "L2 writing."
} 
criteria was that we wanted to limit the scope of our literature search such that the inclusion criteria would enable us to answer our research questions. We also wanted to ensure that our research was replicable. Following these inclusion criteria, we excluded studies that involved ESL students in pre-kindergarten and transitioning from high school to college/university. We reviewed the abstract of each study before applying the inclusion criteria to determine whether to include or exclude it. We read the full article as needed. The search yielded 49 sources, all of which were published in English, and had a North American setting.

Considering the large corpus of sources used in our research, we found that a variety of terminologies were used to describe ESL students, such as English learners, English language learners, multilingual students, and English as an additional language learner, to mention a few. Before including a study in our review, we ensured that it took place in an ESL context, defined as an English learning context in which English is the dominant language outside of the classroom (Coelho, 2016). Also, in some studies, students were identified as bilingual or biliterate (e.g., Abraham, 2017; Midgette \& Philippakos, 2016). They were included in our review since the students were English language learners and were studying in an ESL context (i.e., inclusion criteria [c] above).

\section{Analysis procedures}

A total of 49 studies (see the Appendix) met our inclusion criteria. Of them 43 were qualitative, two were quantitative, and four used both qualitative and quantitative methods. Major theoretical approaches used in these studies were Systemic Functional Linguistics (SFL), genre pedagogy, sociocultural theories, biliteracy, multiliteracy, bilingualism and multilingualism. The main data sources used were interviews, observations, student writing samples, questionnaire surveys, and tests. The duration of studies ranged from four weeks (shortest) to eight years (longest), and the number of participants ranged from one (lowest) to 130 randomly selected students and five teachers (highest). The predominant first languages of participants were Spanish, Korean, Chinese (Mandarin), Vietnamese, Indonesian, Hindi, Finnish, Russian, Gokana, Dutch, and English (some studies had teacher participants whose first language was English).

At the beginning of our analysis process, both of us read all the studies we had retrieved. We prepared a table in a Google document in which we annotated each study we had finished reading. In our annotations, we included information about the focus of the study, context, participants, key findings, and implications. Reading and annotating the studies provided us with a comprehensive understanding about the topic of this review. In particular, the annotations helped us locate the key information to answer the research questions, and revisit the original studies, when necessary.

At the end of the process described above, we established a coding protocol to analyze the data. We adopted an inductive content analysis approach (Stan, 2009). Since the goal of our study was to identify the "challenges" of and "strategies" for ESL writing instruction, we used "challenges of ESL writing instruction" and "strategies for ESL writing instruction" as two broad categories of codes so they aligned with our two research questions. An inductive content analysis approach was deemed suitable as it enabled us to open-code the relevant "concepts" related to "challenges of ESL writing instruction" and "strategies for ESL writing instruction." Once these two broad categories were identified, 
similar concepts were grouped together as sub-categories under them. Initially, each of us worked independently to answer the research questions, followed by a collective discussion for collation of and agreement on the findings. We resolved any disagreements by undertaking additional rounds of reading of the studies and discussion. This iterative process ensured that we completed the analysis systematically and the information gleaned from the analysis was reliable. To further consolidate the reliability of our findings, the coding and categorization done independently were compared and we found a 96\% agreement between the two of us. The emergent coded data were divided into smaller but self-explanatory sub-categories for ease of presentation and discussion of findings (Miles \& Huberman, 1994).

\section{Results}

In the section below we discuss the findings of our review. We have organized the findings in the same order as the research questions stated above.

\section{RQ1: What challenges do teachers encounter in teaching ESL writing in K-12 contexts?}

Our research suggests that teachers encounter a variety of challenges. We have divided these challenges into six sub-categories as follows: (a) lack of pre-service training in ESL writing, (b) lack of writing pedagogy skills, (c) lack of time, (d) lack of professional development opportunities, (e) standardized tests, and (f) unique L1 influences on L2 students' text production. We discuss each of them in the section below.

Lack of pre-service training in ESL writing. Research has highlighted that teachers encounter challenges in various aspects of ESL writing instruction due to a lack of knowledge of the functional aspects of language, engagement with institutional mandates, knowledge of L2 writing theory and pedagogy, fully dedicated courses in L2 writing, practicum and opportunities to observe mentor teachers teach ESL writing, and best practices of feedback, error correction, and assessment (Brisk, 2012; Gebhard et al., 2010; Gilliland, 2015; Larsen, 2013, 2016; Lee, 2016; Yi, 2013). Our analysis suggests that these challenges are attributable to academic training in ESL. Gebhard et al. (2010) found that pre- and in-service teachers may encounter challenges in ESL writing instruction due to a lack of understanding about the functional aspects of language (e.g., how participants construct meaning differently for different purposes using different modes of communication such as written, online or face-to-face) and utilization of the scholarship gleaned from SFL - a theory that recognizes language as "a dynamic system of linguistic choices" that its users make to accomplish various social and academic functions (New London Group, 1996, p. 93). They noted that teachers' lack of critical engagement with various state and federal curricular mandates and collaborative and sustained engagement with different kinds of classroom data through video clips, curricular materials, transcripts, and student texts can also create pedagogical challenges. For example, teachers' lack of knowledge about SFL can constrain their ability to use video clips or student texts as examples of meaning-making resources in their teaching. Similar findings in other studies (Brisk, 2012; Gilliland, 2015) indicated that pre-service teachers may encounter challenges when teaching writing by focusing only on the factual knowledge of language and texts (i.e., knowledge about structural aspects of language) rather than functional knowledge 
(i.e., knowledge about how language is used to produce disciplinary texts) (Bunch, 2013; Fleming et al., 2011, as cited in Gilliland, 2015). Research suggests that academic training should prepare pre-service teachers such that they are ready to work with young L2 writers and deal with various challenges related to the unique characteristics and linguistic needs of these students, offering culturally responsive teaching, acquiring in-depth knowledge about L2 writing pedagogy and theory, and being familiar with best practices in error correction, feedback, and assessment (Larsen, 2013, 2016; Lee, 2016). Another challenge relates to incorporating and sequencing practicum courses in teacher training programs (Lee, 2016; Yi, 2013). Often, these courses are not sequenced in a way so that pre-service teachers have the opportunity to learn L2 writing theories before applying them in the classroom. A related concern is the unavailability of a stand-alone literacy course that trains pre-service teachers with an in-depth orientation about L2 writing and pedagogy (Lee, 2016).

Lack of writing pedagogy skills. A lack of writing pedagogy skills revolves around issues related to stating the expectations of writing tasks explicitly, aligning teachers' understanding and expectations of writing with those of students, good practices in error correction, feedback, and assessment, providing responsive assessment and strategic scaffolding, addressing individual student needs and skills development, use of metalanguage, skills and knowledge to recognize different identities of L2 writers and their specific strengths and weaknesses, and the ability to scrutinize ESL writers' work (Enright \& Gilliland, 2011; Kibler, 2011b; Kibler et al., 2016; Larsen, 2013, 2016; OrtmeierHooper, 2013; Shin, 2016; Wong, 2016). Kibler (2011b) found that tenth grade teachers' expectations about writing tasks were at best implicit, and they shared their expectations with students only through feedback as opposed to explicit "lessons focused on writing" (p. 223). Students' understanding of genre varied and overlapped with that of teachers only partially, and students' and teachers' understanding of what constituted content writing varied from each other. All these factors had a negative impact on writing pedagogy. Kibler (2011b) noted that content area teachers often did not consider themselves as experts in writing. This resulted in students not being taught explicitly about how to write effectively in the content area. Consequently, students' skills for content area writing were underdeveloped. Other studies underlined the importance of teachers' in-depth knowledge of L2 writing pedagogy and assessment practices (Kibler et al., 2016; Larsen, 2016; Wong, 2016) as well as a need for "responsive assessment, instruction, and strategic scaffolding" (Wong, 2016, p. 64). Enright and Gilliland (2011) found that ESL writing teachers did not focus on addressing students' individual needs or skill development. Findings based on a questionnaire survey suggest that ESL writing teachers often feel that they do not have the skills to deal with L2 writing issues in the classroom as writing pedagogy was covered only on the surface in teacher education programs (e.g., Larsen, 2013), or they do not have the metalanguage of writing instruction as part of their pedagogical repertoire required for robust scaffolding for disciplinary language that would involve varying group work and interactions, visuals, sense making materials, and collective and meaningful conversations (Shin, 2016, p. 123). Ortmeier-Hooper's (2013) study highlights the lack of writing pedagogy skills that involve teachers' inability to recognize adolescent L2 writers' identity that profoundly impacts their writing. 
Lack of time. Studies have found that a lack of time can present itself as a potential challenge in ESL writing instruction. For example, Gebhard et al.'s (2010) findings indicate that the teacher had little time and was frustrated that she could not "move them [her students] along as writers" (p. 101). In this context, the teacher did not know how to support her students with explicit writing instruction that would prepare them for the mandated materials. Gebhard et al. (2010) report that it was challenging for the teacher to implement a writing curriculum for which she had little pedagogical support and preparation due to time constraints. In another study, Accurso et al. (2016) found that a lack of preparation time resulted in less collaboration among colleagues and adherence to the district mandated writing curriculum. Consequently, the teacher had to invest a great deal of extra time preparing for tests and designing teaching materials all on her own.

Lack of professional development opportunities. Research suggests that a lack of professional development opportunities may constrain ESL writing instruction. Kibler's (2011b) findings imply that there were no opportunities among content area and language arts teachers to share expertise with each other, which would have contributed to helping improve adolescent L2 writers' content-area writing. Another challenge is teachers were often forced to prepare themselves for teaching mainly through self-study, e.g., by reading books and articles, talking to colleagues, and experimenting due to a lack of professional development opportunities (Larsen, 2013). Soltero-Gonzalez et al.'s (2012) and Yaden and Tsai's (2012) findings underline the concern that without appropriate training and professional development opportunities, teachers will be unable to evaluate the emerging writing of ELL students and know the similarities and differences of the languages students bring into their bilingual classrooms. To illustrate, without appropriate training in or professional development opportunities about the characteristics of ESL texts and writers, teachers may find it challenging to track students' progress in writing.

Standardized tests. A number of studies have noted the constraining effects of standardized tests on ESL writing instruction. It was found that high-stakes tests forced teachers to follow state- or jurisdiction-mandated curriculum for writing instruction (Enright, 2013; Enright \& Gilliland, 2011; Gebhard et al., 2010; Kibler et al., 2016). Following these curriculum mandates resulted in no flexibility in planning and executing creative ways to teach ESL writing. For example, Enright (2013) found that a one-size-fitsall curriculum was not able to address students' individual English language and writing needs, whereas Gilliland (2015) found that teaching writing was constrained by high-stakes writing exams, as teachers were mandated to focus on preparing students for those exams. Kibler et al. (2016) noted that due to high-stakes tests, teachers felt pressured about getting their ELLs to achieve the same standards in writing as non-ELL students. Enright and Gilliland's (2011) findings suggest that broad contextual factors such as district mandates (e.g., No Child Left Behind or NCLB) impacted ESL student writers' writing experiences in significant ways. Multilingual writers were constrained by a number of contingencies because of the NCLB mandate: teachers implemented pedagogical practices to prepare students' writing in different subject matter classes to the district standards and accountability. Any supplementary instructional practice was also planned keeping the goal of preparing students for standardized tests in mind. Consequently, the benchmark 
assessments and state-level assessments were the standards that students were expected to prepare for without any exception. This resulted in students' writing practices being less flexible and creative. Findings showed that ESL student writing was negatively affected as students were required to write according to the district standards regardless of their background preparation in English and interest in writing. Additionally, compliance with district standards trumped all other communicative goals in student writing. Teachers, who had more freedom to encourage ESL students for more authentic communication in courses free from high-stakes assessments, e.g., health class, were able to encourage students to express their perspectives freely. This indicates that accountability is not necessarily a bad thing, but the inflexibility and prescriptive approaches to accountability are. In Accurso et al. (2016), Cecily, the teacher, felt that school reforms were forcing teachers to focus on "writing as a product of testing" (p. 147).

Unique L1 influences on L2 students' text production. Research has shown that students' L1s were responsible for context-specific challenges for ESL writing instruction. Examples include the role of the first language text production in English and textual characteristics of ESL students in K-2 (Abraham, 2017; Gort, 2012a, 2012b; Kibler, 2011a; Mohr, 2017; Raynolds \& Uhry, 2010). Kibler (2011a) explored teacher-student interactions during a writing task and found that it was challenging for the teacher to recognize and address the unique needs of the Spanish-speaking ESL student whose level of English proficiency was extremely low. As a teacher-researcher, Abraham (2017) found that she had to go through the arduous process of actively engaging in identifying the linguistic funds of knowledge specific to her Spanish-English bilingual students in a monolingual classroom. Abraham recognized that teachers in similar contexts should be prepared to do the same. Mohr's (2017) findings suggest that although Grade 2 English learners (EL) demonstrated basic writing skills such as spacing, spelling, capitalization, and punctuation they struggled with descriptive words, closing sentences, transition words, and lead sentences. As well, their writing productivity based on "writing output" and "complexity in expository compositions" (p. 623), was weak, i.e., a score of 3.84 compared with their English-speaking counterparts' 6.18. Raynolds and Uhry (2010) found that Spanish-English bilingual kindergarteners had difficulties spelling stop consonants in English. Other research has investigated textual features of ESL writing. In a bilingual setting, Gort (2012a) investigated challenges children encounter in text production and found that English played a large role in the production of Spanish text, but Spanish did not play a significant role in the production of English text. In a separate study, Gort (2012b) found that emergent Grade 1 Spanish-English bilingual students had the ability to engage in revising texts, and they could do so in both languages. In brief, students' L1s seem to influence their writing in English and consequently, teachers need to be prepared to address this particular challenge in ESL writing instruction.

To summarize, our findings suggest that teachers encounter different challenges in teaching ESL writing in K-12 settings. The main challenge relates to a lack of training in ESL writing in teacher education programs, resulting in their lack of both knowledge and pedagogical skills to teach ESL writing. It also appears that teachers feel pressured due to a lack of time and the requirements for standardized tests, which negatively affect their ESL writing instruction. Finally, a lack of professional development opportunities and 
unique L1 influences on ESL student writers' text production are other challenges that teachers seem to encounter.

RQ2: What strategies can be adopted to help teachers overcome these challenges?

We have divided our findings on strategies to help teachers overcome the challenges they encounter in ESL writing instruction into six sub-categories as follows: (a) incorporating an ESL writing course into teacher education programs, (b) creating opportunities for writing pedagogy support by mentor teachers and researchers, (c) incorporating integrated skills development in the writing classroom, (d) providing students with opportunities to write more, (e) adopting explicit writing instruction, and (f) creating professional development opportunities for teachers. The findings indicate that these strategies are to be adopted not only by pre- or in-service teachers themselves but also by other stakeholders such as program administrators, teacher education programs, school boards and school principals. In the section below, we discuss each of these subcategories.

Incorporating an ESL writing course into teacher education programs. Empirical findings have unequivocally supported inclusion of an ESL writing course in teacher education programs. Such a course should include recent L2 writing theories, characteristics of K-12 ESL student writers and the texts they produce, and strategies for teaching ESL writing. Studies have identified many benefits of a dedicated course on ESL writing methodology in teacher education programs. These benefits include pre-service teachers becoming familiar with ESL writers' unique needs, providing them with an orientation of various cross-cultural aspects of L2 writing, training them in recent L2 writing theories and pedagogies and how to utilize ESL student data in ESL writing instruction. A course on ESL writing methodology in teacher education programs allows pre-service teachers to become familiar with the unique needs and characteristics of ESL writers (Athanases et al., 2013; Lee, 2016). As well, such a course prepares pre-service teachers with effective strategies for ESL writing instruction (Athanases et al., 2013; Brisk, 2012; Lee, 2016; Seloni, 2013; Shin, 2016). Shin (2016) argues that an ESL writing course will help introduce cross-cultural theories of ESL writing and train pre-service teachers on how to use metalanguage as part of their pedagogy. Use of metalanguage enables children to avoid merely reproducing model texts by promoting critical reflection on language use as opposed to rote learning.

One of the implications of Seloni's (2013) findings is that pre-service teachers should be trained to create their own teaching theories based on the local exigencies in which they operate. They should be trained to act like ethnographers and move away from an essentialist approach to language teaching - i.e., an approach to language teaching that is focused exclusively on language forms and structures. Instead, as teachers, they should be cognizant about ESL students' writing based on students' educational backgrounds and sociocultural contexts, and the genre characteristics of the texts students produce. Hodgson-Drysdale's (2016) findings confirm that when teachers are provided with training and support, they can implement SFL-informed writing pedagogy for ELL students, bolstering teacher confidence and efficacy in teaching ESL writing. For example, teachers in Hodgson-Drysdale's study were offered an ongoing PD on the Teaching and Learning 
Cycle (TLC) so they could implement an SFL-informed writing pedagogy and the use of language for meaning-making purposes. Brisk's (2012) findings also suggest that teachers need training in teaching "language in context" (p. 465) in the ESL writing classroom. Athanases et al.'s (2013) findings provide specific guidelines regarding what a teacher education program can do as part of including an ESL writing course. For example, since pre-service teachers must be familiar with their students' writing needs, teacher education programs can train them on how to use students' nested demographic data (e.g., students' cultural backgrounds, first languages, countries of origin, English language levels, socioeconomic backgrounds, and so on), research questions that target the needs of particular students, and collect and analyze a wide range of data such as the ones noted above about students' writing development.

Creating opportunities for writing pedagogy support by mentor teachers and researchers. In addition to including ESL writing courses in teacher education programs, several studies have underlined the importance of pre-service teachers having the opportunities to work closely with mentor teachers and researchers. Using a case study that used researcher journals, written artifacts, non-participant observations and interviews as data sources, Lee's (2016) findings highlight the importance of close working relationships between the teacher education programs and K-12 practicum sites. Lee notes that her study participant, Elaine, could not avail the support of the mentor teacher for her growth as an ESL teacher. In another study, while enrolled in an English Education and Teaching English to Speakers of Other Languages (TESOL) undergraduate program, pre-service teachers made sense of various issues related to L2 writing such as process writing, genrebased teaching, a focus on form versus meaning by reflecting on their observations of senior teachers, ethnographic papers they wrote, and their blog posts (Seloni, 2013). Study findings confirm that pre-service teachers' perspectives about language, culture, and text evolved as they completed their coursework, classroom observations and ethnographic written assignments. Yi (2013) found that pre-service teacher participants wished that they had opportunities for observing their mentor teacher teach writing. In a separate study, Hodgson-Drysdale (2016) found that teachers' level of comfort of adopting the new pedagogy (i.e., SFL-informed writing pedagogy) was dependent upon a number of variables, including support received from the researcher, school principal, and colleagues as well as school-university partnerships. Even though the two teacher participants in Hodgson-Drysdale's research had been teaching for over twenty years they were not familiar with the most recent writing pedagogy such as an SFL-informed view of language use in writing. A collaboration among different stakeholders such as these teachers, researchers, and school principals as well as the school-university partnership made it possible for the teachers to take advantage of an ongoing PD throughout the school year. The PD afforded the teachers to learn about and hone their skills of implementing an SFLinformed writing pedagogy. Finally, research suggests that in secondary school contexts a close working relationship with content-area and writing teachers is a good way to enhance each other's teaching expertise (Kibler, 2011b).

Incorporating integrated skills development in the writing classroom. Several studies have found that a focus on integrated skills development is a useful strategy in ESL 
writing instruction. In particular, findings have shown a strong correlation among expanded and targeted vocabulary development, reading, and writing (e.g., Al-Alawi \& Kohls, 2012; Harman, 2013). For instance, ESL learners' expanded vocabulary helps them process academic texts more easily when they read. Successful comprehension of texts when reading, in turn, helps make their writing fluid (Al-Alawi \& Kohls, 2012). Harman's (2013) study suggests that integrating reading and writing helps literacy development. The teacher's "permeable curricular approach" (p. 137)-i.e., a flexible curriculum that allows for an integration of reading and writing activities - helped the writers view writing as a dialogic activity between literary texts and scaffolding activities in the classroom that enabled students to accomplish their writing resourcefully. For instance, textual scaffolding enabled students to see the specific linguistic forms that are often used in certain kinds of genres (i.e., narrative texts). Additionally, because reading and writing were integrated, students were able to utilize the meaning-making process of various linguistic forms to expand their ideas in writing. As a result, the texts they produced were resourceful in terms of both content and meaning.

In addition to vocabulary, reading, and writing, research has shown that a few other ways that could also contribute positively to students' writing development are: use of communication and mobile technologies, content-area knowledge, a cognitive strategies approach, and multiple literacies. Chen et al.'s (2017) study showed that two ELL students' use of an iPad and digital handwriting app (Penultimate) motivated them to write more. Chen et al.'s findings suggest since these students were motivated to write more, it resulted in enhancement of the quality of their narrative writing. The innovative use of technology in schools improves students' literacy development as well (Gebhard et al., 2011). For example, the teacher used blog-mediated TLC to teach writing to Grade 2 students. These students used blogging to expand their project audiences which contributed to their emerging writing literacy practices. In another study, Shin (2014) identified the important role that blogging played in a Grade 2 ELL student's learning academic writing genres at school. Findings of Shin's (2014) study suggest that the participant, Jose, used blogging (i.e., writing) to increase his social status among his peers. As well, he used blogging to solve his peers' problems.

Olson et al. (2012) found that integrating critical reading and writing skills by adopting innovative means can help enhance students' written literacy. In this study, participating teachers received training in "a cognitive strategies approach to teaching interpretive reading and analytical writing" (p. 323). A cognitive strategies approach utilizes strategies of experienced readers and writers to derive meaning and improve their interpretive reading and analytical writing skills. Later, it was found that students at six secondary schools taught by these teachers achieved higher marks on the California high school exit examination. Analysis of content-area texts (e.g., analyzing texts using SFLbased activities for language forms and meanings), as suggested by Kibler (2011b), can be used in these interpretive reading and analytical writing exercises. Other studies have identified the efficacy of biliteracy in bilingual settings. Findings of Raynolds et al. (2013) and Raynolds and Uhry (2010) indicated a link between L2 vocabulary knowledge and L2 spelling ability of Spanish-English bilingual kindergarten children as they learned new phonemes. 
Providing students with opportunities to write more. Several studies (e.g., Al-Alawi \& Kohls, 2012; Bunch \& Willet, 2013; Gebhard et al., 2011; Yi, 2010; Zapata \& Laman, 2016) have concluded that providing ESL students with opportunities to write more has a positive impact on their writing development. Al-Alawi and Kohls' (2012) participant, Shona, remarked that continual practice or "writing more" (p. 78) helped her to advance her writing skills. Another participant of Al-Alawi and Kohls' (2012), Hassan, opined that extensive writing helped to increase the quality of his writing, sensing that the more he wrote, the more "intelligent" and "knowledgeable" he sounded. Adolescent multilingual writers' in- and out-of-school writing is influenced by each other, so exposure to writing opportunities is the key (Yi, 2010). Bunch and Willet (2013) found that the writing assignment used in their study created opportunities for students to "work with and through language" (p. 157). As part of this writing assignment, students engaged in group activities to persuade their family members to join or oppose Martin Luther in his campaign against the church. Subsequently, students were asked to write a persuasive essay by synthesizing what they had learned in their group activities. Using the persuasive essay prompt enabled students to write for two different audiences: the teacher and their imagined family members. As a result, students were trained in utilizing language creatively and purposefully.

In addition to the above, researchers have identified how exposure to writing transforms ESL writers in various ways. Brown (2016) found that a digital approach to writing enhanced social interactions among student writers with different skills and abilities, which contributed to their success. The digital approach to writing entailed ELL students' use of Barnes \& Nobles' e-reader called the Nook that enabled them to read children's literature and other texts, and respond to what they read in writing using an ejournal App. As well, these young writers relied on each other and positioned themselves as experts. Kibler (2010) found that classroom interactions during an extended writing activity in which secondary ESL students used their native languages to discuss ideas for writing helped develop their English writing skills. Zapata and Laman (2016) found that creating opportunities for students to write more contributes to translingual practices- "a pedagogic theory that involves students' learning of two languages through a process of deep cognitive bilingual engagement" (Garcia \& Wei, 2014, p. 64, italics original) -in writing in the multilingual classroom, which helps students' identity development, innovative language use as well as their development as bilingual writers. For specific examples of translingual practices among students, please see Zapata and Laman (2016), p. 366.

A number of studies have looked into the impact of different contexts on student writing. For instance, Gebhard et al. (2011) found that their study participant, Diany, used blogging to apologize, praise, joke, thank, and provide and accept feedback. As part of the blog-mediated TLC, the students utilized blogging to expand their writing skills in combination with classroom-based face-to-face instruction. Through the functions of apologizing, praising, joking, and exchanging feedback, Diany used blogging, sometimes subtly and at other times overtly, to experiment with the functional aspects of language. Snow et al. (2016) focused on kindergarten students (three children in a mixed group with two ESL and one American) engaging in literacy-enriched play, whereby children were provided opportunities for literacy development through play, and how it affected the 
children's emerging writing development and their writing behaviors. Using blocks during literacy-enriched play, the researchers found that the children drew pictures of different characters to use in their block games. The process demonstrated children's ability of meaning-making to encode stories they wanted to tell. The findings indicated that teachers may want to encourage students of different cultural and language backgrounds to play together for effective writing development. Hong (2015) studied 19 kindergarten ELL children's becoming a writer by using writing workshops consisting of "mini lesson [on a non-fiction writing unit], independent writing/conferring, sharing, and publication" (p. 306). Hong noted that by the end of the workshops the ELL students evolved from "others as authors" to "self as an author" to "self as a reflective writer" (p. 301).

Research has focused on strategies to create an optimal impact of exposure to writing opportunities on student writers. Bauer et al. (2017) employed "buddy pairs" in the classroom, which was found to foster translingual practices. The teacher chose students to form a "buddy pair" with consideration of their demographic backgrounds, academic experiences, and strengths. The findings showed that students who were grouped in a "buddy pair" demonstrated more willingness to interact with each other, which ultimately shaped their writing. Shin (2014) noted the importance of valuing ELLs' social, linguistic, and personal lives outside school for effective (writing) literacy development. For instance, her findings suggest that writing practice through blogging as a way of socialization played an important role in the student's awareness of the interpersonal functions of text, how different ideas are embedded into texts and academic genres. A common theme that emerges from these studies is that for ELL students to flourish in literacy development, instructors must tap into students' current social and cultural resources by bridging the gap between students' life in and outside of school. Midgette and Philippakos (2016) found that having students write interactive journals to teachers as audience can maximize the impact of writing exposure.

Adopting explicit writing instruction. Much research indicates that explicit writing instruction helps improve young ESL students' writing skills. One of the most common instructional approaches that a number of studies (e.g., De Oliveira \& Lan, 2014; Harman, 2013; Hodgson-Drysdale, 2016; O'Hallaron, 2014; Shin, 2016) have explored is genreand SFL-based pedagogy. Kibler's (2011b) findings indicated that genre-based teaching, whereby teachers identify a specific genre (e.g., business report) and its structures, give examples, and provide students with specific writing goals so they can produce texts that align with the target genre, might be relevant to adolescent ESL instruction. In another study, it was found that genre-based instruction on writing argumentative essays helped students produce better quality texts (O'Hallaron, 2014). The opportunity for an engagement with the source text, genre-based instruction, and teacher's scaffolding helped improve student writing. O'Hallaron (2014) also highlighted the importance of targeted ESL writing instruction, e.g., teaching argumentative writing. Harman (2013) noted the efficacy of adopting both an SFL and genre approach to ESL writing instruction. The researcher found that a genre-based pedagogy afforded student writers different resources to draw on to accomplish their writing as they learned to view language as a "pliable" resource. Through explicit instruction, the teacher was able to help students recognize language as a tool for meaning making and the intertextual nature of writing. An SFL 
perspective helped teachers "analyze with students how academic and literary texts linguistically construe knowledge" (Harman, 2013, p. 137). De Oliveira and Lan (2014) offered concrete evidence of a positive impact of a genre-based approach to teaching science writing to a fourth grade ELL student, demonstrating that the explicitness and precision of the procedural recount writing of the ELL student improved after genre-based instruction. It was found that the student used more field-specific vocabulary and technical terms, and the text had an enhanced quality of cohesion and coherence due to the use of temporal connectors (e.g., first, then, finally). An SFL-informed pedagogy was also reported to improve teachers' writing instruction and help improve the quality of student texts (Hodgson-Drysdale, 2016). Shin's (2016) findings show that when ELL students wrote science reports using science-related discourses, the scaffolding the teacher used (e.g., graphic organizers, scientific language and vocabulary, and metalanguage about scientific genres) made it easier for students to write those reports. Because of SFLinformed pedagogy, the first-grade ELL was able to produce a topic-centered, coherent report with a domain-specific linguistic repertoire, and was able to use metalanguage in eliciting the meaning of science reports. Findings of a different study by Brisk (2012) showed how a focus on "genre (purpose), mode (spoken or written), and tenor (audience and voice)" (p. 466) can help teachers teaching ESL writing. A genre approach to writing instruction, whereby teachers focus on the use of language in context, allows them to teach students the functional aspects of language when producing academic texts. This results in students making choices about their language use in writing with an awareness of the audience rather than following a set of fixed rules in text production.

Besides SFL and genre-based pedagogy, research has identified other instructional strategies that had a positive impact on ESL student writing. Brisk et al.'s (2016) findings indicated that writing instruction that was intentional and focused on character development helped four fourth grade bilingual writers' fictional narratives, and that the features of the characters in the narratives helped move the plot. The teachers used a number of instructional strategies: using mentor texts and explicitly exploring characters in these texts; explicitly demonstrating how characters are developed, and guiding the students to develop their own characters by various activities such as drawings, using graphic organizers, and conferencing with students. Students were trained on how to use images such as graphic organizers and other language resources to "enhance their narratives and reveal features of their characters" (p. 103). The study showed that young L2 writers can excel in a second language and a difficult genre (i.e., fictional narrative) if they receive targeted instruction. Mohr's (2017) findings indicated that a Modeled Writing (MW) approach, whereby the teacher used a text to model the genre and the act of writing itself to model writing, was effective for writing instruction for Grade 2 students. In another study by Accurso et al. (2016), Cecily, the teacher, made the following pedagogical choices: she valued the knowledge and linguistic resources that ELLs brought to the classroom; strategically selected grade-level model texts for students so they had opportunities to try out new language practices both in small groups and individually; highlighted the social function of linguistic choices, so students could critically examine their language in writing to communicate ideas meaningfully; and dedicated much time to students' drafting and revising phases. These pedagogical choices by the teacher helped the student, Ana Sofia, draw on a variety of linguistic resources to accomplish her science 
writing. Studying a Korean middle school ESL student, Pandey (2012) stressed the need for a hybrid methodology for writing instruction, incorporating inductive instruction for morphology, grammar, paragraph, and discourse structures as well as thesis statement construction. The author noted the efficacy of individual student-centered writing classrooms that offered one-on-one workshop-style, individualized teaching. Finally, Yi (2010) found that the teacher's positive comments helped improve student writing.

Creating professional development opportunities for teachers. While a lack of professional development opportunities for teachers has been identified as one of the challenges in ESL writing instruction, several studies (Babinski et al., 2018; Brisk, 2012; Brisk \& Zisselsberger, 2010; Olson et al., 2012) have found positive impacts of professional development opportunities for teachers on ESL writing instruction. Babinski et al. (2018) investigated a professional development intervention program called Developing Collaboration and Consultation Skills (DCCS) (p.118), which included ongoing collaboration between ESL and classroom teachers. The ESL and classroom teachers collaborated on implementation strategies of evidence-based teaching practices. This collaboration also included incorporating ESL learners' and their families' 'cultural wealth" (Yosso, 2005, p. 119) into language and literacy pedagogy. The authors found that ESL students were likely to benefit from their teachers' professional development as they achieved higher scores in the Woodcock Munoz Language Survey (WMLS). Brisk and Zisselsberger's (2010) findings suggest that professional development in SFL had a positive impact on writing instruction, as students' writing improved when they had been "let in on the secret of how, in the context of American culture, text is created" (p. 118). Because of professional development opportunities, teachers felt more confident about their teaching of writing. Brisk's (2012) findings pointed out that the professional development programs the teachers were part of yielded benefits to ESL writing instruction. Olson et al. (2012) reported that after 72 teachers were assigned to participate in the Pathway Project, "a cognitive strategies approach to teaching interpretive reading and analytical writing" (p. 323), as part of a professional development program, the intervention resulted in students achieving higher scores on examinations. Athanases et al. (2013) found that through professional development programs, pre-service teachers can be prepared early in their careers for collecting and analyzing student-based data to inform their classroom practices.

In sum, findings point to several strategies that can be adopted to overcome the challenges teachers encounter in K-12 ESL writing instruction. First, training pre-service teachers in ESL writing should be a priority for teacher education programs. Next, it is a good idea to create a support network for teachers by enlisting the help of mentor teachers and researchers from local post-secondary institutions. For teachers themselves, a few helpful strategies may include incorporating integrated skills development in the writing classroom, creating opportunities for students to write more both inside and outside of the classroom, and adopting explicit writing instruction for student learning. Finally, a helpful strategy is to create professional development opportunities for teachers' ongoing learning. 


\section{Discussion}

This systematic literature review provides an overview of the state of affairs of K12 ESL writing instruction with regard to the challenges teachers encounter and what can be done to help them overcome these challenges. In short, it appears that ESL writing instruction at the K-12 level is an area that does not receive much attention in teacher education programs, and teachers, when teaching ESL writing, tend to encounter a variety of challenges because of this. That said, research has shed light on strategies that can be adopted to help teachers overcome the challenges.

Although teachers may encounter a variety of challenges when teaching in the classroom a closer look at the nature and type of the challenges they encounter in ESL writing instruction can provide critical insights into the limitations of teacher education programs. The findings show that ESL writing instruction is an area that requires both specialized knowledge and skills (Kibler et al., 2016). For example, without a working knowledge about writing as a complex literacy skill and the unique characteristics of ESL student writers, their writing processes, the errors they typically make, and the characteristics of the texts they produce, teachers would likely struggle in their teaching. Teachers cannot make informed decisions about the kind of pedagogical interventions necessary in a particular teaching context without being able to make sense of the types of errors in student writing. Similarly, without knowledge about writing and the functional aspects of language, it is difficult to plan and implement effective classroom pedagogy. Consequently, it is imperative that these concerns are appropriately addressed in teacher education programs.

In addition to the above, there appear to be challenges that teachers may encounter due to various external factors such as the pressures of standardized tests, a lack of prep time, and a lack of opportunities for professional development (Kibler, 2011b; Lee, 2016). Although high-stakes tests such as the ones related to No Child Left Behind (NCLB) in the U.S. provide a measure of students' academic achievement, concerted efforts are necessary among the state/provincial, district, and school stakeholders to help ELLs develop basic literacy skills, including those in writing, at an early age so they are primed for academic success. This follows that the stakeholders need to review and set academic priorities for ELLs. Findings suggest that ELLs can engage in highly effective literacy practices in the classroom, even with their developing English language proficiency. Consequently, it rests upon the teachers, administrators, and policy makers to make the best of ESL students' abilities. Various stakeholders need to work collaboratively to address the challenge of a lack of prep time and professional development opportunities for teachers. To illustrate, in-service teachers, especially those who have no background in teaching ESL writing or those who have just started their teaching career, can be considered for release from some teaching time. This is possible only when stakeholders are intentional, and resources are available for school principals. Similarly, although professional development interventions (Athanases, et al., 2013; Brisk, 2012; Kibler, 2011b; Lee, 2016) can help teachers compensate for a lack of academic training in ESL writing, opportunities for professional development have to be created at the school by various parties working collaboratively. What this means is that the school principal and school board must recognize the importance of professional development for ESL teachers and consider giving release time from their day-to-day teaching schedules. To illustrate, if teachers are encouraged to 
organize and participate in professional development, their release time will translate into creating effective learning opportunities for them. Opportunities for learning for ESL teachers can also be created by collaborating with local post-secondary institutions and inviting researchers to schools. The researchers can observe teachers teach and provide them with constructive feedback based on the latest empirical evidence and teachinglearning theories. Collaboration between content area and ESL teachers can enhance teaching effectiveness for both.

In spite of various challenges in ESL writing instruction, research has shed light on a number of useful strategies, ranging from explicit instruction to incorporating integrated skills development (Al-Alawi \& Kohls, 2012; Harman, 2013) and using SFL and genre pedagogy (Accurso et al., 2016; Brisk \& Zisselsberger, 2010; O'Hallaron, 2014); from partnerships with mentor teachers (Lee, 2016; Yi, 2013) to giving students opportunities to write more (Bauer et al., 2017; Midgette \& Philippakos, 2016; Shin, 2014). It is important to note that teachers alone cannot implement these strategies, as research suggests that different stakeholders need to work together to make classroom ESL writing instruction effective. For example, schools and teacher education programs need to work together to provide pre-service teachers optimal opportunities for class observations, reflection, and ultimately, building robust teaching partnerships with mentor teachers (Lee, 2016; Yi, 2013). Findings suggest that these strategies have a positive impact on the quality of student learning.

Our findings suggest that teachers' thinking that K-12 students' English writing development can only be achieved in a monolingual classroom setting needs to change. Empirical evidence indicates that biliteracy development occurs even when students have developing language skills in either of the languages, and that students are adept at transferring literacy skills from one language to another (Kibler, 2010, 2011a). This suggests that there is no need for an exclusive use of English in the ESL writing classroom. In fact, students should be encouraged to use their native languages when engaging in ESL writing activities. Also important is to reject the flawed belief that writing is not important for elementary students' second language development (Larsen, 2016). Considering that K-12 classrooms are replete with diverse students with myriad linguistic and cultural backgrounds, an effective strategy for teachers is to utilize students' diverse backgrounds as resources to strengthen student learning. This strategy works well in classroom settings that are varied with bilingual, ESL, refugee, and emergent bilingual students (Accurso et al., 2016; Bunch \& Willet, 2013; Ortmeier-Hooper, 2013; Wong, 2016).

\section{Conclusion}

This systematic literature review provides insights into the extant empirical evidence on challenges teachers encounter in teaching ESL writing and strategies to overcome them. Thus, the paper provides useful insights for teachers, teacher education program administrators, and policy makers. This review also illuminates the work K-12 ESL teachers and researchers are doing to help ESL children develop their writing skills. It is encouraging to see that new research on K-12 ESL writing is emerging, enriching the field of L2 writing in general.

This review has important implications for research on K-12 ESL writing instruction, in particular, as they relate to Canadian schools. As is evident from the review, 
research on K-12 ESL writing instruction in Canadian contexts is almost non-existent (only one out of 49 studies reviewed in this paper took place in Canada). Consequently, there is very little empirical evidence on the challenges teachers in Canadian schools encounter while teaching writing to ESL students. Similarly, we know little about the effective strategies teachers are already using and the support they need. It is imperative to gather empirical evidence on these important issues to enhance the overall quality of K-12 literacy education. Considering the high percentage of ESL students in Canadian schools today, as discussed in the introduction of this paper, there is no alternative to gathering empirical evidence on the current state of affairs of ESL writing instruction. To begin with, this can be done by posing such research questions as: How is ESL writing taught in Canadian K12 schools? How prepared do teachers feel about teaching ESL writing? What challenges do teachers face in teaching ESL writing? What support do they need? and so on. While the insights from this paper can provide starting points for teachers, researchers, teacher education programs and school boards to plan for enhancing K-12 ESL writing education, more empirical research is necessary to gain a more nuanced, context-specific understanding about the issue.

Finally, a limitation of this work is that all studies reviewed in this paper were published in English. Another limitation is that the studies reviewed took place in North America. Consequently, this review does not include research in other K-12 ESL contexts such as the UK, Australia or New Zealand as well as English as a Foreign Language (EFL) contexts. To gain a more comprehensive understanding about K-12 L2 writing, accounting for these contexts is important.

\section{Acknowledgement}

The authors would like to acknowledge the detailed feedback received from two anonymous reviewers that helped strengthen the paper.

\section{References}

Abraham, S. L. (2017). A teacher's inquiry into bringing in biliteracy in a fifth-grade English-only classroom. Networks: An Online Journal for Teacher Research, 19(1), 1-16. https://doi.org/10.4148/2470-6353.1009

Accurso, K., Gebhard, M., \& Selden, C. (2016). Supporting L2 elementary science writing with SFL in an age of school reform. In L. C. de Oliveira \& T. Silva (Eds.), Second language writing in elementary classrooms: Instructional issues, content-area writing and teacher education (pp. 126-150). Palgrave Macmillan.

Al-Alawi, M., \& Kohls, R. (2012). Writing practices and achievement. In A. Cumming (Ed.), Adolescent literacies in a multicultural context (pp. 74-86). Routledge.

Athanases, S. Z., Bennett, L. H., \& Wahleithner, J. M. (2013). Responsive teacher inquiry for learning about adolescent English learners as developing writers. In T. Silva \& L. C. Olivereira (Eds.), L2 writing in secondary classrooms: Student experiences, academic issues, and teacher education (pp. 149-165). Taylor and Francis.

Babinski, L.M., Amendum, S.J., Knotek, S.E., Sanchez, M., \& Malone, P. (2018). 
Improving young English learners' language and literacy skills through teacher professional development: A randomized controlled trial. American Educational Research Journal, 55(1), 117-143. https://doi.org/10.3102/0002831217732335

Bauer, E. B., Presiado, V., \& Colomer, S. (2017). Writing through partnership: Fostering translanguaging in children who are emergent bilinguals. Journal of Literacy Research, 49(1), 10-37. https://doi.org/10.1177/1086296X16683417

Brisk, M.E. (2012). Young bilingual writers' control of grammatical person in different genres. The Elementary School Journal, 112(3), 445-468. http://doi.org/10.1086/663733

Brisk, M. E., Nelson, D., \& O'Connor, C. (2016). Bilingual fourth graders develop a central character for their narratives. In L. C. de Oliveira \& T. Silva (Eds.), Second language writing in elementary classrooms: Instructional issues, contentarea writing and teacher education (pp. 88-105). Palgrave Macmillan.

Brisk, M.A., \& Zisselsberger, M. (2010). "We've let them in on a secret" Using SFL theory to improve the teaching of writing to bilingual learners. In T. Lucas (Ed.), Teacher preparation for linguistically diverse classrooms: A resource for teacher educators (pp. 111-126). Taylor \& Francis Group.

Brown, S. (2016). E-journaling in response to digital texts. In L. C. de Oliveira \& T. Silva (Eds.), Second language writing in elementary classrooms: Instructional issues, content-area writing and teacher education (pp. 13-32). Palgrave Macmillan.

Bunch, G. C., \& Willet, K. (2013). Writing to mean in middle school: Understanding how second language writers negotiate textually-rich content-area instruction. Journal of Second Language Writing, 22(2), 141-160. http://doi.org/10.1016/j.jslw.2013.03.007

Calgary Board of Education. (2017). Calgary Board of Education (CBE) Financial Review Report. https://education.alberta.ca/media/3739809/cbereport_04apr18.pdf

CBC News. (2018, November, 21). Alberta school board calls on province for more resources for students learning English. https://www.cbc.ca/news/canada/calgary/english-language-learners-albertaschool-boards-1.4915661

Chen, Y., Carger, C.L., Smith, T. J. (2017). Mobile-assisted narrative writing practice for young English language learners from a funds of knowledge approach. Language Learning \& Technology, 21(1), 28-41. http://doi.org/10125/44594

Coelho, E. (2016). Adding English: A guide to teaching in multilingual classrooms. University of Toronto Press.

De Oliveira, L. C., \& Lan, S. W. (2014). Writing science in an upper elementary classroom: A genre-based approach to teaching English language learners. Journal of Second Language Writing, 25, 23-39. https://doi.org/10.1016/j.jslw.2014.05.001

English Language Learning (ELL) Teaching Resources. (2020, August 27). Resources for teachers. https://www2.gov.bc.ca/gov/content/education-training/k12/teach/resources-for-teachers/english-language-learning

Enright, K. A. (2013). Adolescent writers and academic trajectories situating L2 writing 
in the content areas. In T. Silva \& L.C. de Oliveira (Eds.), L2 writing in secondary classrooms: Student experiences, academic issues, and teacher education (pp. 27-43). Taylor \& Francis.

Enright, K. A., \& Gilliland, B. (2011). Multilingual writing in an age of accountability: From policy to practice in U.S. high school classrooms. Journal of Second Language Writing, 20(3), 182-195. https://doi.org/10.1016/j.jslw.2011.05.006

Fleming, D., Francis, B., \& Osnat, F. (2011). ESL teacher-candidates' beliefs about language. TESL Canada Journal, 29(1), 39-56. https://doi.org/10.18806/tesl.v29i1.1088

Follert, J. (2019, February 5). Number of 'English language learners' doubles in Durham schools. The Star. https://www.thestar.com/news/gta/2019/02/05/number-ofenglish-language-learners-doubles-in-durhan-schools.html

Garcia, O., \& Wei, L. (2014). Translanguaging: Language, bilingualism and education. Palgrave Macmillan. https://doi.org/10.1057/9781137385765

Gebhard, M., Shin, D., \& Seger, W. (2011). Blogging and emergent L2 literacy development in an urban elementary school: A functional perspective. CALICO Journal, 28(2), 1-22. http://doi.org/10.11139/cj.28.2.278-307

Gebhard, M., Willett, J., Jiménez Caicedo, J. P., \& Piedra, A. (2010). Systemic functional linguistics, teachers' professional development, and ELLs' academic literacy practices. In T. Lucas (Ed.), Teacher preparation for linguistically diverse classrooms: A resource for teacher educators (pp. 91-110). Taylor \& Francis Group.

Gilliland, B. (2015). High school teacher perspectives and practice: Second language writing and language development. Language and Education 29(4), 287-301. https://doi.org/10.1080/09500782.2014.1001398

Gort, M. (2012a). Code-switching patterns in the writing related talk of young emergent bilinguals. Journal of Literacy Research, 44(1), 45-75. https://doi.org/10.1177/1086296X11431626

Gort, M. (2012b). Evaluation and revision processes of young bilinguals in a dual language program. In E. B. Bauer \& M. Gort (Eds.), Early biliteracy development exploring young learners' use of their linguistic resources (pp. 90 -110). Routledge.

Guo, Y., Maitra, S., \& Guo, S. (2019). "I belong to nowhere": Syrian refugee children's perspectives on school integration. The Journal of Contemporary Issues in Education, 14(1), 89-105. https://doi.org/10.20355/jcie29362

Harman, R. (2013). Literary intertextuality in genre-based pedagogies: Building lexical cohesion in fifth-grade L2 writing. Journal of Second Language Writing, 22(2), 125-140. https://doi.org/10.1016/j.jslw.2013.03.006

Hirvela, A., \& Belcher, D. (2007). Writing scholars as teacher educators: Exploring writing teacher education. Journal of Second Language Writing, 16(3), 125-128. https://doi.org/10.1016/j.jslw.2007.08.001

Hodgson-Drysdale, T. (2016). Teaching writing through genres and language. In L. C. de Oliveira \& T. Silva (Eds.), Second language writing in elementary classrooms: Instructional issues, content-area writing and teacher education (pp. 69-87). Palgrave Macmillan. 
Hong, H. (2015). Exploring young children's writer identity construction through the lens of dialogism. International Journal of Early Childhood, 47(2), 301-316. https://doi.org/10.1007/s13158-015-0136-y

Huie, K. \& Yahya, N. (2003). Learning to write in the primary grades: Experiences of English language learners and mainstream students. TESOL Journal, 12(1), 2531. https://doi.org/10.1002/j.1949-3533.2003.tb00116.x

Kibler, A. (2010). Writing through two languages: First language expertise in a language minority classroom. Journal of Second Language Writing, 19(3), 121-142. http://doi.org/10.1016/j.jslw.2010.04.001

Kibler, A. (2011a). "Casi nomás me dicen qué escribir/They almost just tell me what to write": A longitudinal analysis of teacher-student interactions in a linguistically diverse mainstream secondary classroom. Journal of Education, 191(1), 45-58. https://doi.org/10.1177/002205741119100105

Kibler, A. (2011b). "I write it in a way that people can read it": How teachers and adolescent L2 writers describe content area writing. Journal of Second Language Writing, 20(3), 211-226. https://doi.org/10.1016/j.jslw.2011.05.005

Kibler, A., Heny, N., \& Andrei, E. (2016). In-service teachers' perspectives on adolescent writing instruction. TESOL Journal, 7(2), 350-392. https://doi.org/10.1002/tesj.211

Larsen, D. (2013). Focus on pre-service teacher preparation for ESL writing instruction. In L. C. de Oliveira \& T. Silva (Eds.), L2 writing in secondary classrooms: Student experiences, academic issues, and teacher education (pp. 119-132). Routledge.

Larsen, D. (2016). Pre-service teacher preparation for L2 writing: Perspectives of inservice elementary ESL teachers. In L. C. de Oliveira \& T. Silva (Eds.), Second language writing in elementary classrooms: Instructional issues, content-area writing and teacher education (pp. 172-190). Palgrave Macmillan.

Lee, S. H. (2016). Bridging the in- and out-of-school writing practices of ELLs through postmethod pedagogy: One elementary teacher's journey. In L. C. de Oliveira \& T. Silva (Eds.), Second language writing in elementary classrooms: Instructional issues, content-area writing and teacher education (pp. 153-171). Palgrave Macmillan.

Matsuda, P. K., \& De Pew, K. E. (2002). Early second language writing: An introduction. Journal of Second Language Writing, 11(4), 261-268. https://doi.org/10.1016/S1060-3743(02)00087-5

Midgette, E., \& Philippakos, Z.A. (2016). Biliteracy, spelling, and writing: A case study. The Language and Literacy Spectrum, 26, 13-30.

Miles, M. B., \& Huberman, A. M. (1994). Qualitative data analysis: An expanded sourcebook. Sage.

Mohr, K.A.J. (2017). Using modeled writing to support English-only and English-learner second-grade students. The Journal of Educational Research, 110(6), 619-633. https://doi.org/10.1080/00220671.2016.1169391

New London Group. (1996). A pedagogy of multiliteracies: Designing social features. Harvard Educational Review, 66(1), 60-92. https://doi.org/10.17763/haer.66.1.17370n67v22j160u 
O’Hallaron, C. L. (2014). Supporting fifth-grade ELLs' argumentative writing development. Written Communication, 31(3), 304-331. https://doi.org/10.1177/0741088314536524

Olson, C.B., Kim, J. S., Scarcella, R., Kramer, J., Pearson, M., van Dyk, D. A., Collins, P., \& Land, R.E. (2012). Enhancing the interpretive reading and analytical writing of mainstreamed English learners in Second School: Results from a randomized field trial using a cognitive strategies approach. American Educational Research Journal, 49(2), 323-355. https://doi.org/10.3102/0002831212439434

Ortmeier-Hooper, C. (2013). "She doesn't know who I am” The case of a refugee L2 writer in a high school English language arts classroom. In T. Silva \& L. C. Olivereira (Eds.), L2 writing in secondary classrooms: Student experiences, academic issues, and teacher education (pp. 9-26). Taylor and Francis.

Ortmeier-Hooper, C., \& Enright, K. A. (2011). Mapping new territory: Toward an understanding of adolescent L2 writers and writing in US contexts. Journal of Second Language Writing, 20(3), 167-181. https://doi.org/10.1016/j.jslw.2011.05.002

Ontario Education. (2007). English language learners ESL and ELD programs and services. http://www.edu.gov.on.ca/eng/document/esleldprograms/esleldprograms.pdf

Pandey, A. (2012). Rethinking process-based writing approach in the ESOL middle school classroom: Developing linguistic fluency via hybrid pedagogies. TESOL Journal, 3(4), 659-697. https://doi.org/10.1002/tesj.39

Pavlov, V. (2015). Challenges faced by English language learners on the Alberta English language arts 30-1 reading diploma examination. [Doctoral thesis, University of Calgary]. https://prism.ucalgary.ca/handle/11023/2660

Petticrew, M., \& Roberts, H. (2006). Systematic review in the social sciences: A practical guide. Blackwell. http://doi.org/10.1002/9780470754887

Raynolds, L. B., \& Uhry, J. K. (2010). The invented spellings of non-Spanish phonemes by Spanish-English bilingual and English monolingual kindergarteners. Reading and Writing, 23(5), 495-513. https://doi.org/10.1007/s11145-009-9169-7

Raynolds, L. B., Uhry, J. K., \& Brunner, J. (2013). Vowel representations in the invented spellings of Spanish-English bilingual kindergartners. Reading and Writing, 26(5), 647-664. https://doi.org/10.1007/s11145-012-9380-9

Roessingh, H. (2004). Effective ESL programs: A synthesis and meta-analysis. The Canadian Modern Language Review, 60(5), 611-636. https://doi.org/10.3138/cmlr.60.5.611

Roessingh, H. (2008). Variability in ESL outcomes: The influence of age on arrival and length of residence on achievement in high school. TESL Canada Journal, 26(1), 87-107. https://doi.org/10.18806/tesl.v26i1.392

Roessingh, H. (2018). Unmasking the early language and literacy needs of ELLs: What K-3 practitioners need to know and do. BC TEAL Journal, 3(1), 22-36. https://doi.org/10.14288/bctj.v3i1.276

Roessingh, H., \& Douglas, S. R. (2012). English Language Learners' transitional needs 
from high school to university: An exploratory study. Journal of International Migration and Integration, 13, 285-301. https://doi.org/10.1007/s12134-011$\underline{0202-8}$

Roessingh, H., \& Elgie, S. (2009). Early language and literacy development among young English language learners: Preliminary insights from a longitudinal study. TESL Canada Journal, 26(2), 24-45. https://doi.org/10.18806/tesl.v26i2.413

Roessingh, H., \& Kover, P. (2002). Working with younger-arriving ESL learners in high school English: Never too late to reclaim potential. TESL Canada Journal, 19(2), 1-20. https://doi.org/10.18806/tesl.v19i2.926

Roessingh, H., Nordstokke, \& Colp, M. (2019a). Beyond presentation effects: Understanding the role of handwriting in the holistic rating of young students' writing in Grade 4. Alberta Journal of Educational Research, 65(1), 72-93. https://doi.org/10.11575/ajer.v65i1.56630

Roessingh, H., Nordstokke,, \& Colp, M. (2019b). Unlocking academic literacy in Grade 4: The role of handwriting. Reading \& Writing Quarterly, 35(2), 65-83. https://doi.org/10.1080/10573569.2018.1499160

Schulz, M. M. (2009). Effective writing assessment and instruction for young English language learners. Early Childhood Education Journal, 37(1), 57-62. https://doi.org/10.1007/s10643-009-0317-0

Seloni, L. (2013). Understanding how pre-service teachers develop a working knowledge of L2 writing: Toward a sociocultural oriented postmethod pedagogy. In L. C. de Oliveira \& T. Silva (Eds.), L2 writing in secondary classrooms: Student experiences, academic issues, and teacher education (pp. 167-189). Routledge.

Shin, D. (2014). Web 2.0 tools and academic literacy development in a US urban school: A case study of a second-grade English language learner. Language and Education, 28(1), 68-85. https://doi.org/10.1080/09500782.2013.771653

Shin, D. (2016). Disciplinary language development in writing: Science reports and common core state standards. In L. C. de Oliveira \& T. Silva (Eds.), Second language writing in elementary classrooms: Instructional issues, content-area writing and teacher education (pp. 106-125). Palgrave Macmillan.

Snow, M., Eslami, Z.R., \& Park, J. H. (2016). English language learners' writing behaviours during literacy-enriched block play. Journal of Early Childhood Literacy, 18(2), 189-213. https://doi.org/10.1177/1468798416637113

Soltero-Gonzalez, L., Escamilla, K., \& Hopewell, S. (2012). Changing teachers' perceptions about the writing abilities of emerging bilingual students: Towards a holistic bilingual perspective on writing assessment. International Journal of Bilingual Education and Bilingualism, 15(1), 71-94. https://doi.org/10.1080/13670050.2011.604712

Sparrow, W., Butvilofsky, S., \& Escamilla, K. (2012). The evolution of biliterate writing development through simultaneous bilingual literacy instruction. In E. Bouchereau Bauer \& M. Gort (Eds.), Early biliteracy development exploring young learners' use of their linguistic resources (pp. 156-181). Routledge.

Stan, L. (2009). Content analysis. In A. J. Mills, G. Durepos, \& E. Wiebe (Eds.), Encyclopedia of Case Study Research (Vol. 1, pp. 226-230). Sage. https://www.doi.org/10.4135/9781412957397.n85 
Sweet, R., Pullman, A., Adamuti-Trache, M., \& Robson, K. (2019). Ethno-linguistic patterns of degree completion in BC universities: How important are high school academic achievement and institution of entry? Canadian Journal of Higher Education, 49(3), 69-87. https://doi.org/10.7202/1066636ar

The Government of British Columbia. (2020, August 27). English Language Learning (ELL) Teaching Resources. Education and training. https://www2.gov.bc.ca/gov/content/education-training/k-12/teach/resources-forteachers/english-language-learning

Toohey, K., \& Derwing, T. M. (2008). Hidden losses: Demographics can encourage incorrect assumptions about ESL high school students' success. The Alberta Journal of Educational Research, 54(2), 178-193. https://doi.org/10.11575/ajer.v54i2.55221

Williams, C., \& Lowrance-Faulhaber, E. (2018). Writing in young bilingual children: Review of research. Journal of Second Language Writing, 42, 58-69. https://doi.org/10.1016/j.jslw.2018.10.012

Wong, J. W. (2016). Leveraging hidden resources to navigate tensions and challenges in writing: A case study of a fourth-grade emergent bilingual student. In L. C. de Oliveira \& T. Silva (Eds.), Second language writing in elementary classrooms: Instructional issues, content-area writing and teacher education (pp. 47-66). Palgrave Macmillan.

Yaden, D., \& Tsai, T. (2012). Learning how to write in English and Chinese young bilingual kindergarten and first grade children explore the similarities and differences between writing systems. In E. Bouchereau Bauer \& M. Gort (Eds.), Early biliteracy development exploring young learners' use of their linguistic resources (pp. 55-83). Routledge.

Yi, Y. (2010). Adolescent multilingual writers' transitions across in- and out-of-school writing contexts. Journal of Second Language Writing, 19(1), 17-32. https://doi.org/10.1016/j.jslw.2009.10.001

Yi, Y. (2013). ESOL teachers as writing teachers: From the voices of high school preservice teachers. In L. C. de Oliveira \& T. Silva (Eds.), L2 writing in secondary classrooms: Student experiences, academic issues, and teacher education (pp. 133-148). Routledge.

Yosso, T. J. (2005). Whose culture has capital? A critical race theory discussion of community cultural wealth. Race, Ethnicity and Education, 8(1), 69-91. https://doi.org/10.1080/1361332052000341006

Zapata, A., \& Laman, T. T. (2016). "I write to show how beautiful my languages are": Translingual writing instruction in English-dominant classrooms. Language Arts, 93(5), 366-378. https://www.jstor.org/stable/44809858

Author Biographies

Subrata Bhowmik is a senior instructor in the Werklund School of Education at the University of Calgary. His academic interests include L2 writing and sociocultural approaches to L2 learning. 
Marcia Kim is an instructor in the Werklund School of Education at the University of Calgary. Her research interests are in the areas of English as an Additional Language, applied linguistics, and teacher education. 
Appendix

\begin{tabular}{|c|c|c|c|c|c|c|}
\hline Study & Purpose or Focus & $\begin{array}{l}\text { Theoretical } \\
\text { Framework }\end{array}$ & $\begin{array}{l}\text { Participant } \\
\text { Number, Age } \\
\text { and/or Grade }\end{array}$ & $\begin{array}{l}\text { Participants' } \\
\text { Dominant } \\
\text { Language }\end{array}$ & $\begin{array}{l}\text { Duration of } \\
\text { the Study }\end{array}$ & $\begin{array}{l}\text { Research Method and/or } \\
\text { Data Sources }\end{array}$ \\
\hline $\begin{array}{l}\text { Abraham } \\
(2017)\end{array}$ & $\begin{array}{l}\text { A teacher's } \\
\text { examination of a } \\
\text { question about } \\
\text { teaching writing }\end{array}$ & $\begin{array}{l}\text { Funds of } \\
\text { knowledge; teacher } \\
\text { research }\end{array}$ & $\begin{array}{l}\text { Grade } 5 \\
\text { bilingual } \\
\text { Spanish-English } \\
\text { students }\end{array}$ & Spanish & $\begin{array}{l}\text { One school } \\
\text { year }\end{array}$ & Interviews, observations \\
\hline $\begin{array}{l}\text { Accurso, } \\
\text { Gebhard \& } \\
\text { Selden }(2016)\end{array}$ & $\begin{array}{l}\text { Development and } \\
\text { implementation of } \\
\text { science writing }\end{array}$ & $\begin{array}{l}\text { Systemic } \\
\text { Functional } \\
\text { Linguistics and } \\
\text { functional } \\
\text { perspective of } \\
\text { grammar, genre } \\
\text { pedagogy }\end{array}$ & $\begin{array}{l}\text { An ELL teacher } \\
\text { called Cecily; a } \\
\text { fourth-grade } \\
\text { bilingual student } \\
\text { called Ana Sofia }\end{array}$ & $\begin{array}{l}\text { Student - } \\
\text { Spanish }\end{array}$ & 2013-2014 & Writing samples \\
\hline $\begin{array}{l}\text { Al-Alawi \& } \\
\text { Kohls (2012) }\end{array}$ & $\begin{array}{l}\text { Students' writing } \\
\text { practices, } \\
\text { achievements, } \\
\text { difficulties, and the } \\
\text { quality of texts they } \\
\text { produced }\end{array}$ & & 18 students & & Four years & $\begin{array}{l}\text { Longitudinal, comparative, } \\
\text { collaborative, standardized } \\
\text { tests, interviews, surveys, } \\
\text { microgenetic case studies of } \\
\text { tutoring and learning }\end{array}$ \\
\hline $\begin{array}{l}\text { Athanases, } \\
\text { Bennett \& } \\
\text { Wahleithner } \\
\text { (2013) }\end{array}$ & $\begin{array}{l}\text { Pre-service teachers } \\
\text { and adolescent } \\
\text { ELLs' writing } \\
\text { development }\end{array}$ & $\begin{array}{l}\text { Teacher inquiry } \\
\text { guided by } \\
\text { intentional, } \\
\text { systematic work } \\
\text { (Cochran-Smith \& } \\
\text { Lytle, 2009) }\end{array}$ & $\begin{array}{l}96 \text { secondary } \\
\text { pre-service } \\
\text { teachers }\end{array}$ & & 10 months & $\begin{array}{l}\text { collected information about } \\
\text { students; mentoring } \\
\text { conferences; field notes }\end{array}$ \\
\hline
\end{tabular}




\begin{tabular}{|c|c|c|c|c|c|c|}
\hline Study & Purpose or Focus & $\begin{array}{l}\text { Theoretical } \\
\text { Framework }\end{array}$ & $\begin{array}{l}\text { Participant } \\
\text { Number, Age } \\
\text { and/or Grade }\end{array}$ & $\begin{array}{l}\text { Participants' } \\
\text { Dominant } \\
\text { Language }\end{array}$ & $\begin{array}{l}\text { Duration of } \\
\text { the Study }\end{array}$ & $\begin{array}{l}\text { Research Method and/or } \\
\text { Data Sources }\end{array}$ \\
\hline $\begin{array}{l}\text { Babinski, } \\
\text { Amendum, } \\
\text { Knotek, } \\
\text { Sanchez \& } \\
\text { Malone } \\
(2018)\end{array}$ & $\begin{array}{l}\text { Professional } \\
\text { development } \\
\text { intervention program } \\
\text { for teachers }\end{array}$ & & $\begin{array}{l}45 \text { teachers, } 105 \\
\text { students in } 12 \\
\text { elementary } \\
\text { schools }\end{array}$ & $\begin{array}{l}\text { Students } \\
\text { were Spanish } \\
\text { speakers }\end{array}$ & & $\begin{array}{l}\text { School based teams } \\
\text { randomly assigned to the } \\
\text { intervention; pre- and post } \\
\text { test data; observation tool; } \\
\text { Woodcock Munoz Language } \\
\text { Survey-Revised Normative } \\
\text { Update (WMLS-R; Schrank, } \\
\text { McGrew, \& Dailey, 2010) }\end{array}$ \\
\hline $\begin{array}{l}\text { Bauer, } \\
\text { Presiado \& } \\
\text { Colomer } \\
(2017)\end{array}$ & $\begin{array}{l}\text { The use of "buddy } \\
\text { pairs" with emergent } \\
\text { bilingual students }\end{array}$ & Translanguaging & $\begin{array}{l}\text { Two emergent } \\
\text { bilingual } \\
\text { kindergarteners; } \\
\text { teacher became a } \\
\text { participant- } \\
\text { observer }\end{array}$ & $\begin{array}{l}\text { Spanish, } \\
\text { English; } \\
\text { teacher- } \\
\text { Spanish- } \\
\text { English } \\
\text { bilingual }\end{array}$ & $2013-2014$ & $\begin{array}{l}\text { Case study; writing samples, } \\
\text { field notes, daily writing } \\
\text { journal, }\end{array}$ \\
\hline Brisk (2012) & $\begin{array}{l}\text { Students' } \\
\text { understanding of } \\
\text { genre and audience }\end{array}$ & $\begin{array}{l}\text { Systemic } \\
\text { Functional } \\
\text { Linguistics }\end{array}$ & $\begin{array}{l}\text { Grades } 3 \text { to } 5 \\
\text { ESL writers-- } \\
\text { eight boys and } \\
\text { five girls }\end{array}$ & $\begin{array}{l}\text { Spanish and } \\
\text { Vietnamese }\end{array}$ & $\begin{array}{l}\text { One school } \\
\text { year; PDs }\end{array}$ & 112 written texts; field notes \\
\hline $\begin{array}{l}\text { Brisk, Nelson } \\
\text { \& O’Connor } \\
(2016)\end{array}$ & $\begin{array}{l}\text { Bilingual students' } \\
\text { development of } \\
\text { characters in } \\
\text { fictional writing }\end{array}$ & $\begin{array}{l}\text { Teaching and } \\
\text { Learning Cycle } \\
\text { (TLC) (Rothery, } \\
\text { 1996) }\end{array}$ & $\begin{array}{l}\text { Four Grade } 4 \\
\text { bilingual } \\
\text { students and } \\
\text { authors Cheryl } \\
\text { and Deb }\end{array}$ & $\begin{array}{l}\text { Cape } \\
\text { Verdean, } \\
\text { Spanish, } \\
\text { Indonesian } \\
\text { and } \\
\text { Vietnamese }\end{array}$ & & $\begin{array}{l}\text { Field notes, narratives, } \\
\text { drawings, graphic organizers }\end{array}$ \\
\hline
\end{tabular}




\begin{tabular}{|c|c|c|c|c|c|c|}
\hline Study & Purpose or Focus & $\begin{array}{l}\text { Theoretical } \\
\text { Framework }\end{array}$ & $\begin{array}{l}\text { Participant } \\
\text { Number, Age } \\
\text { and/or Grade }\end{array}$ & $\begin{array}{l}\text { Participants' } \\
\text { Dominant } \\
\text { Language }\end{array}$ & $\begin{array}{l}\text { Duration of } \\
\text { the Study }\end{array}$ & $\begin{array}{l}\text { Research Method and/or } \\
\text { Data Sources }\end{array}$ \\
\hline $\begin{array}{l}\text { Brisk \& } \\
\text { Zisselsberger } \\
(2010)\end{array}$ & $\begin{array}{l}\text { The impact of } \\
\text { professional } \\
\text { development } \\
\text { program on an SFL- } \\
\text { based approach to } \\
\text { teaching writing }\end{array}$ & SFL theory & 11 teachers & & $\begin{array}{l}\text { Seven two- } \\
\text { hour } \\
\text { sessions }\end{array}$ & $\begin{array}{l}\text { PD materials, observations, } \\
\text { discussions with teachers, } \\
\text { student writing }\end{array}$ \\
\hline Brown (2016) & $\begin{array}{l}\text { Multimedia digital } \\
\text { writing tools for } \\
\text { children's literacy } \\
\text { development }\end{array}$ & $\begin{array}{l}\text { multimodal } \\
\text { literacies }\end{array}$ & $\begin{array}{l}\text { Six third grade } \\
\text { ELLs }\end{array}$ & & $\begin{array}{l}\text { One school } \\
\text { year }\end{array}$ & $\begin{array}{l}\text { Qualitative study; videotaped } \\
\text { events; field notes; screen } \\
\text { shots of students' writing }\end{array}$ \\
\hline $\begin{array}{l}\text { Bunch \& } \\
\text { Willet (2013) }\end{array}$ & $\begin{array}{l}\text { Middle school ESL } \\
\text { students' essay } \\
\text { assignments in social } \\
\text { studies }\end{array}$ & $\begin{array}{l}\text { Writing as } \\
\text { meaning-making }\end{array}$ & $\begin{array}{l}40 \text { students with } \\
\text { varying English } \\
\text { proficiency } \\
\text { levels }\end{array}$ & Spanish & $\begin{array}{l}\text { One school } \\
\text { year }\end{array}$ & 41 essays \\
\hline $\begin{array}{l}\text { Chen, Carger } \\
\text { \& Smith } \\
(2017)\end{array}$ & $\begin{array}{l}\text { Narrative writing } \\
\text { practice of young } \\
\text { ELLs who used } \\
\text { iPads }\end{array}$ & $\begin{array}{l}\text { Funds of } \\
\text { knowledge } \\
\text { approach }\end{array}$ & $\begin{array}{l}\text { Grade } 7 \text { Chinese } \\
\text { girl and 13-year- } \\
\text { old Mexican- } \\
\text { American boy } \\
\text { called Larry }\end{array}$ & $\begin{array}{l}\text { Mandarin and } \\
\text { Spanish }\end{array}$ & Four weeks & $\begin{array}{l}\text { Instrumental case study; } \\
\text { home-visits, interviews, } \\
\text { questionnaires, pre- and post- } \\
\text { essays, informal } \\
\text { observations, and field notes }\end{array}$ \\
\hline $\begin{array}{l}\text { De Oliveira } \\
\& \text { Lan (2014) }\end{array}$ & $\begin{array}{l}\text { Genre-based } \\
\text { approach to teaching } \\
\text { science writing to a } \\
\text { fourth grade ELL } \\
\text { student }\end{array}$ & $\begin{array}{l}\text { Systemic } \\
\text { Functional } \\
\text { Linguistics (SFL); } \\
\text { Teaching and } \\
\text { Learning Cycle by } \\
\text { Rothery (1994) }\end{array}$ & $\begin{array}{l}\text { An ELL from } \\
\text { Korea }\end{array}$ & Korean & $\begin{array}{l}\text { Second } \\
\text { phase } \\
\text { (January to } \\
\text { March } \\
\text { 2011) of a } \\
\text { four-year } \\
\text { project }\end{array}$ & $\begin{array}{l}\text { Case study; meetings with } \\
\text { teacher, observations, pre- } \\
\text { and post-genre student } \\
\text { writing, notes from meetings, } \\
\text { field notes, and transcripts }\end{array}$ \\
\hline
\end{tabular}




\begin{tabular}{|c|c|c|c|c|c|c|}
\hline Study & Purpose or Focus & $\begin{array}{l}\text { Theoretical } \\
\text { Framework }\end{array}$ & $\begin{array}{l}\text { Participant } \\
\text { Number, Age } \\
\text { and/or Grade }\end{array}$ & $\begin{array}{l}\text { Participants' } \\
\text { Dominant } \\
\text { Language }\end{array}$ & $\begin{array}{l}\text { Duration of } \\
\text { the Study }\end{array}$ & $\begin{array}{l}\text { Research Method and/or } \\
\text { Data Sources }\end{array}$ \\
\hline $\begin{array}{l}\text { Enright } \\
(2013)\end{array}$ & $\begin{array}{l}\text { Two ELL students } \\
\text { and how context } \\
\text { impacted their } \\
\text { writing experiences }\end{array}$ & $\begin{array}{l}\text { Language } \\
\text { socialization }\end{array}$ & $\begin{array}{l}\text { Two 9th grade } \\
\text { L2 writers }\end{array}$ & Spanish & $\begin{array}{l}\text { Researchers } \\
\text { followed a } \\
\text { particular } \\
\text { class } \\
\text { schedule } \\
\text { three days a } \\
\text { week }\end{array}$ & $\begin{array}{l}\text { Audio-recorded classroom, } \\
\text { small group discussions } \\
\text { classroom artifacts, copies of } \\
\text { curriculum materials, student } \\
\text { work, interviews }\end{array}$ \\
\hline $\begin{array}{l}\text { Enright \& } \\
\text { Gilliland } \\
(2011)\end{array}$ & $\begin{array}{l}\text { The influence of } \\
\text { accountability efforts } \\
\text { on writing practices } \\
\text { of multilingual } \\
\text { student writers }\end{array}$ & $\begin{array}{l}\text { Academic } \\
\text { socialization and } \\
\text { academic literacies }\end{array}$ & $\begin{array}{l}130 \text { randomly } \\
\text { selected students } \\
\text { and } 5 \text { teachers }\end{array}$ & & $\begin{array}{l}2007-2008 \\
\text { school year }\end{array}$ & $\begin{array}{l}\text { Classroom artifacts, field } \\
\text { notes, meetings with the } \\
\text { school leadership team, } \\
\text { school staff, faculty; school } \\
\text { documents }\end{array}$ \\
\hline $\begin{array}{l}\text { Gebhard, } \\
\text { Shin \& Seger } \\
(2011)\end{array}$ & $\begin{array}{l}\text { A teacher's use of } \\
\text { SFL to design a } \\
\text { blog-mediated } \\
\text { writing curriculum } \\
\text { for an ELL's literacy } \\
\text { development }\end{array}$ & $\begin{array}{l}\text { Martin's SFL- } \\
\text { based genre } \\
\text { theory; Vygotskian } \\
\text { concepts of } \\
\text { appropriation and } \\
\text { mediation }\end{array}$ & $\begin{array}{l}\text { A student named } \\
\text { Diany from } \\
\text { Puerto Rico; a } \\
\text { teacher named } \\
\text { Mrs. Seger }\end{array}$ & $\begin{array}{l}\text { Spanish; } \\
\text { teacher is } \\
\text { conversationa } \\
\text { lly fluent in } \\
\text { Spanish }\end{array}$ & 22 months & $\begin{array}{l}\text { Classroom ethnography and } \\
\text { genre analysis using the tools } \\
\text { of SFL; curricular materials; } \\
\text { and ELL produced texts }\end{array}$ \\
\hline $\begin{array}{l}\text { Gebhard, } \\
\text { Willet, } \\
\text { Jiménez } \\
\text { Caicedo \& } \\
\text { Piedra (2010) }\end{array}$ & $\begin{array}{l}\text { District-university } \\
\text { partnership, } \\
\text { supporting teachers } \\
\text { to use content-based } \\
\text { language approach } \\
\end{array}$ & $\begin{array}{l}\text { Systemic } \\
\text { Functional } \\
\text { Linguistics and } \\
\text { academic literacy } \\
\text { development } \\
\end{array}$ & $\begin{array}{l}\text { One teacher } \\
\text { named Amy } \\
\text { Piedra; an ELL } \\
\text { student named } \\
\text { Eloy } \\
\end{array}$ & Spanish & $\begin{array}{l}\text { August } \\
2004 \text { - May } \\
2005\end{array}$ & Ethnographic case study \\
\hline $\begin{array}{l}\text { Gilliland } \\
(2015)\end{array}$ & $\begin{array}{l}\text { Teachers' } \\
\text { understanding of }\end{array}$ & $\begin{array}{l}\text { Academic literacy } \\
\text { (Street, 2012) }\end{array}$ & $\begin{array}{l}\text { Two high school } \\
\text { teachers }\end{array}$ & English & One year & $\begin{array}{l}\text { Ethnography; interview and } \\
\text { audio recordings of class } \\
\text { sessions }\end{array}$ \\
\hline
\end{tabular}




\begin{tabular}{|c|c|c|c|c|c|c|}
\hline Study & Purpose or Focus & $\begin{array}{l}\text { Theoretical } \\
\text { Framework }\end{array}$ & $\begin{array}{l}\text { Participant } \\
\text { Number, Age } \\
\text { and/or Grade }\end{array}$ & $\begin{array}{l}\text { Participants' } \\
\text { Dominant } \\
\text { Language }\end{array}$ & $\begin{array}{l}\text { Duration of } \\
\text { the Study }\end{array}$ & $\begin{array}{l}\text { Research Method and/or } \\
\text { Data Sources }\end{array}$ \\
\hline & $\begin{array}{l}\text { second language } \\
\text { learning and their } \\
\text { practices }\end{array}$ & & & & & \\
\hline Gort (2012a) & $\begin{array}{l}\text { The role of code } \\
\text { switching in writing } \\
\text { development }\end{array}$ & $\begin{array}{l}\text { Code-switching; } \\
\text { the role of talk and } \\
\text { social interaction }\end{array}$ & $\begin{array}{l}6 \text { emergent } \\
\text { Spanish-English } \\
\text { bilingual grade } \\
\text { one children }\end{array}$ & Spanish & Six months & $\begin{array}{l}\text { Audio recordings, field } \\
\text { notes, writing artifacts }\end{array}$ \\
\hline Gort (2012b) & $\begin{array}{l}\text { Writing and revising } \\
\text { practices of bilingual } \\
\text { students }\end{array}$ & $\begin{array}{l}\text { Revising process; } \\
\text { metalinguistic } \\
\text { awareness; } \\
\text { biliteracy; } \\
\text { bilingualism }\end{array}$ & $\begin{array}{l}\text { Three English } \\
\text { dominant and } \\
\text { three Spanish } \\
\text { dominant } \\
\text { students }\end{array}$ & $\begin{array}{l}\text { English and } \\
\text { Spanish }\end{array}$ & Six months & $\begin{array}{l}\text { Observations; writing } \\
\text { samples, audio tapes, field } \\
\text { notes; interviews }\end{array}$ \\
\hline $\begin{array}{l}\text { Harman } \\
(2013)\end{array}$ & $\begin{array}{l}\text { A teacher's genre- } \\
\text { based pedagogy of } \\
\text { using expanded } \\
\text { linguistic choices in } \\
\text { genre writing of } \\
\text { literary narratives }\end{array}$ & $\begin{array}{l}\text { Systemic } \\
\text { Functional } \\
\text { Linguistics }\end{array}$ & $\begin{array}{l}\text { Two grade } 5 \\
\text { Spanish-English } \\
\text { bilingual } \\
\text { students; their } \\
\text { teacher }\end{array}$ & & $\begin{array}{l}\text { September } \\
2004 \text { - April } \\
2005\end{array}$ & $\begin{array}{l}\text { Audio and video recordings } \\
\text { of interviews and interactions } \\
\text { in the classroom, student } \\
\text { writing, field notes, teaching } \\
\text { materials, children's } \\
\text { literature, course assignment, } \\
\text { documents }\end{array}$ \\
\hline $\begin{array}{l}\text { Hodgson- } \\
\text { Drysdale } \\
(2016)\end{array}$ & $\begin{array}{l}\text { Systemic Functional } \\
\text { Linguistics and } \\
\text { teachers teaching of } \\
\text { writing }\end{array}$ & $\begin{array}{l}\text { Systemic } \\
\text { Functional } \\
\text { Linguistics }\end{array}$ & $\begin{array}{l}\text { Two teachers } \\
\text { called Eva and } \\
\text { Myrna }\end{array}$ & & $\begin{array}{l}\text { Eva - One } \\
\text { school year; } \\
\text { Myrna - } 10 \\
\text { months }\end{array}$ & $\begin{array}{l}\text { Modified form of action } \\
\text { research; observations and } \\
\text { field notes }\end{array}$ \\
\hline
\end{tabular}




\begin{tabular}{|c|c|c|c|c|c|c|}
\hline Study & Purpose or Focus & $\begin{array}{l}\text { Theoretical } \\
\text { Framework }\end{array}$ & $\begin{array}{l}\text { Participant } \\
\text { Number, Age } \\
\text { and/or Grade }\end{array}$ & $\begin{array}{l}\text { Participants' } \\
\text { Dominant } \\
\text { Language }\end{array}$ & $\begin{array}{l}\text { Duration of } \\
\text { the Study }\end{array}$ & $\begin{array}{l}\text { Research Method and/or } \\
\text { Data Sources }\end{array}$ \\
\hline Hong (2015) & $\begin{array}{l}\text { Understanding how } \\
\text { ELLs become writers } \\
\text { over time }\end{array}$ & $\begin{array}{l}\text { Bakhtinian } \\
\text { dialogism and } \\
\text { interactional } \\
\text { sociolinguistics }\end{array}$ & $\begin{array}{l}19 \text { children and } \\
\text { one teacher } \\
\text { called Ms. } \\
\text { Young }\end{array}$ & $\begin{array}{l}\text { Hindi, } \\
\text { Spanish, } \\
\text { Finnish and } \\
\text { Russsian } \\
\end{array}$ & One year & $\begin{array}{l}\text { Ethnography; discourse } \\
\text { analysis on videos of three } \\
\text { literacy events chosen from } \\
\text { writing units }\end{array}$ \\
\hline Kibler (2010) & $\begin{array}{l}\text { Oral interactions of } \\
\text { ESL writers during } \\
\text { writing activity }\end{array}$ & $\begin{array}{l}\text { Interactional } \\
\text { sociolinguistics }\end{array}$ & $\begin{array}{l}\text { Teacher and four } \\
\text { focal students }\end{array}$ & Spanish & & $\begin{array}{l}\text { Ethnographic, field notes and } \\
\text { audio recordings, and student } \\
\text { writing }\end{array}$ \\
\hline $\begin{array}{l}\text { Kibler } \\
\text { (2011a) }\end{array}$ & $\begin{array}{l}\text { The challenges of } \\
\text { teacher-student } \\
\text { interactions in a } \\
\text { writing class }\end{array}$ & $\begin{array}{l}\text { Interactional } \\
\text { histories analysis } \\
\text { and multimodal } \\
\text { analysis }\end{array}$ & $\begin{array}{l}\text { One Grade } 10 \\
\text { student and his } \\
\text { teacher }\end{array}$ & $\begin{array}{l}\text { Spanish; } \\
\text { English }\end{array}$ & & $\begin{array}{l}\text { Case study; ethnographic } \\
\text { observations, interviews; } \\
\text { student writing; transcription }\end{array}$ \\
\hline $\begin{array}{l}\text { Kibler } \\
(2011 b)\end{array}$ & $\begin{array}{l}\text { Teachers' and } \\
\text { students' } \\
\text { perspectives on the } \\
\text { expectations about } \\
\text { writing tasks }\end{array}$ & & $\begin{array}{l}\text { Four 10th grade } \\
\text { ESL writers and } \\
\text { two of their } \\
\text { teachers }\end{array}$ & Spanish & Two years & $\begin{array}{l}\text { Ethnographic study; } \\
\text { fieldnotes, interviews, and } \\
\text { student writing samples, } \\
\text { informal observations }\end{array}$ \\
\hline $\begin{array}{l}\text { Kibler, Heny } \\
\text { \& Andrei } \\
(2016)\end{array}$ & $\begin{array}{l}\text { Teachers' } \\
\text { perspectives on } \\
\text { adolescent ELL } \\
\text { writing instruction }\end{array}$ & $\begin{array}{l}\text { Ecological } \\
\text { language learning } \\
\text { theories and } \\
\text { situated teacher } \\
\text { learning theory }\end{array}$ & $\begin{array}{l}10 \text { secondary } \\
\text { teachers }\end{array}$ & English & & $\begin{array}{l}\text { Exploratory study; focus } \\
\text { group and follow up } \\
\text { interviews }\end{array}$ \\
\hline
\end{tabular}




\begin{tabular}{|c|c|c|c|c|c|c|}
\hline Study & Purpose or Focus & $\begin{array}{l}\text { Theoretical } \\
\text { Framework }\end{array}$ & $\begin{array}{l}\text { Participant } \\
\text { Number, Age } \\
\text { and/or Grade }\end{array}$ & $\begin{array}{l}\text { Participants' } \\
\text { Dominant } \\
\text { Language }\end{array}$ & $\begin{array}{l}\text { Duration of } \\
\text { the Study }\end{array}$ & $\begin{array}{l}\text { Research Method and/or } \\
\text { Data Sources }\end{array}$ \\
\hline Larsen (2013) & $\begin{array}{l}\text { Teachers' } \\
\text { preparedness of } \\
\text { teachers dealing with } \\
\text { ESL student writing }\end{array}$ & & $\begin{array}{l}54 \text { secondary } \\
\text { ESL teachers }\end{array}$ & & & Questionnaire survey \\
\hline Larsen (2016) & $\begin{array}{l}\text { Elementary ESL } \\
\text { teachers' work with } \\
\text { student writing; } \\
\text { requirements for } \\
\text { ESL teacher } \\
\text { education programs }\end{array}$ & & $\begin{array}{l}51 \text { elementary } \\
\text { ESL teachers }\end{array}$ & & & Questionnaire survey \\
\hline Lee (2016) & $\begin{array}{l}\text { An in-service } \\
\text { teacher's journey in } \\
\text { a TESOL graduate } \\
\text { education program }\end{array}$ & $\begin{array}{l}\mathrm{Bi} / \text { multi-literacy } \\
\text { and postmethod } \\
\text { pedagogy }\end{array}$ & $\begin{array}{l}\text { A grade } 5 \\
\text { teacher, Elaine }\end{array}$ & English & & $\begin{array}{l}\text { Case study; researcher } \\
\text { journal, written artifacts, } \\
\text { non-participant observations, } \\
\text { end of program interview }\end{array}$ \\
\hline $\begin{array}{l}\text { Midgette \& } \\
\text { Philippakos } \\
\text { (2016) }\end{array}$ & $\begin{array}{l}\text { A biliterate } \\
\text { kindergarten student } \\
\text { learning English } \\
\text { spelling }\end{array}$ & $\begin{array}{l}\text { Gentry's (1982) } \\
\text { principles of } \\
\text { correctness of } \\
\text { English } \\
\text { orthography }\end{array}$ & $\begin{array}{l}\text { One female } \\
\text { kindergarten } \\
\text { learner named } \\
\text { Vikka }\end{array}$ & Russian & $\begin{array}{l}\text { Seven } \\
\text { months }\end{array}$ & $\begin{array}{l}\text { Case study; student's } \\
\text { responses to in-class writing } \\
\text { tasks }\end{array}$ \\
\hline Mohr (2017) & $\begin{array}{l}\text { Writing of English } \\
\text { language learning } \\
\text { and native English } \\
\text { speaking students } \\
\text { before and after a }\end{array}$ & $\begin{array}{l}\text { Sociocognitive } \\
\text { theory of language } \\
\text { development; } \\
\text { informational } \\
\text { writing instruction }\end{array}$ & $\begin{array}{l}N=105 ; 70 \\
\text { English learners } \\
\text { (ELs) and native } \\
\text { English speaking } \\
\text { second graders; } \\
8 \text { teachers }\end{array}$ & $\begin{array}{l}\text { Spanish; } \\
\text { English }\end{array}$ & One year & Formative design experiment \\
\hline
\end{tabular}




\begin{tabular}{|c|c|c|c|c|c|c|}
\hline Study & Purpose or Focus & $\begin{array}{l}\text { Theoretical } \\
\text { Framework }\end{array}$ & $\begin{array}{l}\text { Participant } \\
\text { Number, Age } \\
\text { and/or Grade }\end{array}$ & $\begin{array}{l}\text { Participants' } \\
\text { Dominant } \\
\text { Language }\end{array}$ & $\begin{array}{l}\text { Duration of } \\
\text { the Study }\end{array}$ & $\begin{array}{l}\text { Research Method and/or } \\
\text { Data Sources }\end{array}$ \\
\hline & $\begin{array}{l}\text { year-long writing } \\
\text { program }\end{array}$ & & & & & \\
\hline $\begin{array}{l}\text { O'Hallaron } \\
\text { (2014) }\end{array}$ & $\begin{array}{l}\text { Instruction } \\
\text { supporting } \\
\text { argumentative } \\
\text { writing of fifth-grade } \\
\text { ELLs }\end{array}$ & $\begin{array}{l}\text { Functional } \\
\text { grammar which } \\
\text { draws on Systemic } \\
\text { Functional } \\
\text { Linguistics }\end{array}$ & $\begin{array}{l}\text { Two teachers } \\
\text { from grade } 2 \text { to } 5\end{array}$ & $\begin{array}{l}\text { One of the } \\
\text { teachers was } \\
\text { bilingual } \\
\text { English and } \\
\text { Arabic }\end{array}$ & $\begin{array}{l}\text { One school } \\
\text { year }\end{array}$ & $\begin{array}{l}\text { Students' final drafts, } \\
\text { graphic organizers, } \\
\text { classroom video and audio } \\
\text { data, texts }\end{array}$ \\
\hline $\begin{array}{l}\text { Olson, Kim, } \\
\text { Scarcella, } \\
\text { Kramer, } \\
\text { Pearson, van } \\
\text { Dyk, Collins } \\
\text { \& Land } \\
(2012) \\
\end{array}$ & $\begin{array}{l}\text { Teachers and the } \\
\text { Pathway Project, a } \\
\text { cognitive strategies } \\
\text { approach to teaching. }\end{array}$ & $\begin{array}{l}\text { Students were } \\
\text { taught cognitive } \\
\text { strategies }\end{array}$ & $\begin{array}{l}72 \text { secondary } \\
\text { teachers; } 9 \\
\text { middle schools } \\
\text { and } 6 \text { high } \\
\text { schools }\end{array}$ & & $\begin{array}{l}2007-2008 \\
2008-2009\end{array}$ & $\begin{array}{l}\text { Multi-site cluster randomized } \\
\text { field trial }\end{array}$ \\
\hline $\begin{array}{l}\text { Ortmeier- } \\
\text { Hooper } \\
(2013)\end{array}$ & $\begin{array}{l}\text { A refugee student's } \\
\text { conflict of identity } \\
\text { with his teacher's } \\
\text { perception of him }\end{array}$ & $\begin{array}{l}\text { Multilingual } \\
\text { writers' identity } \\
\text { within the } \\
\text { framework of } \\
\text { teacher perception } \\
\text { (Chiang \& } \\
\text { Schmida, 1999); } \\
\text { Teacher-student } \\
\text { relationships } \\
\text { (Blanton, 2002 } \\
\text { 2005); }\end{array}$ & $\begin{array}{l}\text { A 14-year old } \\
\text { refugee from } \\
\text { student Nigeria, } \\
\text { Wisdom; an } \\
\text { English language } \\
\text { teacher of } 15 \\
\text { years, Mrs. } \\
\text { Jennens }\end{array}$ & Gokana & 15 months & $\begin{array}{l}\text { Case study; field } \\
\text { observations and notes, } \\
\text { interviews and transcripts, } \\
\text { informal interviews with } \\
\text { Wisdom's peers, writing } \\
\text { samples }\end{array}$ \\
\hline
\end{tabular}




\begin{tabular}{|c|c|c|c|c|c|c|}
\hline Study & Purpose or Focus & $\begin{array}{l}\text { Theoretical } \\
\text { Framework }\end{array}$ & $\begin{array}{l}\text { Participant } \\
\text { Number, Age } \\
\text { and/or Grade }\end{array}$ & $\begin{array}{l}\text { Participants' } \\
\text { Dominant } \\
\text { Language }\end{array}$ & $\begin{array}{l}\text { Duration of } \\
\text { the Study }\end{array}$ & $\begin{array}{l}\text { Research Method and/or } \\
\text { Data Sources }\end{array}$ \\
\hline $\begin{array}{l}\text { Pandey } \\
(2012)\end{array}$ & $\begin{array}{l}\text { Examining the } \\
\text { efficacy of a process } \\
\text { approach to teaching } \\
\text { ESL writing }\end{array}$ & $\begin{array}{l}\text { Contrastive } \\
\text { rhetoric; MAP } \\
\text { (meaningful, } \\
\text { authentic, } \\
\text { purposeful) model }\end{array}$ & $\begin{array}{l}\text { A Korean grade } \\
\text { eight student }\end{array}$ & Korean & & $\begin{array}{l}\text { Detailed, longitudinal case } \\
\text { study }\end{array}$ \\
\hline $\begin{array}{l}\text { Raynolds \& } \\
\text { Uhry (2010) }\end{array}$ & $\begin{array}{l}\text { A comparison of the } \\
\text { spelling of Spanish- } \\
\text { English bilingual } \\
\text { kindergarteners with } \\
\text { their English- } \\
\text { speaking } \\
\text { monolingual } \\
\text { counterparts }\end{array}$ & $\begin{array}{l}\text { Lexical } \\
\text { restructuring } \\
\text { model }\end{array}$ & $\begin{array}{l}38 \text { kindergarten } \\
\text { students }\end{array}$ & $\begin{array}{l}\text { Spanish and } \\
\text { English }\end{array}$ & $\begin{array}{l}\text { April and } \\
\text { May }\end{array}$ & $\begin{array}{l}\text { Literacy screening, spelling } \\
\text { assessment and vocabulary } \\
\text { test }\end{array}$ \\
\hline $\begin{array}{l}\text { Raynolds, } \\
\text { Uhry \& } \\
\text { Brunner } \\
(2013)\end{array}$ & $\begin{array}{l}\text { Phonic instruction } \\
\text { and its impact on the } \\
\text { invented spellings of } \\
\text { the second language } \\
\text { vowel phonemes }\end{array}$ & & $\begin{array}{l}19 \text { ELL } \\
\text { kindergarteners } \\
\text { and } 19 \\
\text { monolingual }\end{array}$ & $\begin{array}{l}\text { Spanish and } \\
\text { English }\end{array}$ & $\begin{array}{l}\text { Two } \\
\text { months }\end{array}$ & $\begin{array}{l}\text { Assessment tests (PPVT-III, } \\
\text { PALS) }\end{array}$ \\
\hline Seloni (2013) & $\begin{array}{l}\text { Pre-service teachers' } \\
\text { real life experiences } \\
\text { with language, } \\
\text { culture, and text and } \\
\text { their mediation }\end{array}$ & $\begin{array}{l}\text { Post-method } \\
\text { pedagogy and } \\
\text { sociocultural } \\
\text { perspectives of } \\
\text { teacher education }\end{array}$ & $\begin{array}{l}\text { Four pre-service } \\
\text { teachers }\end{array}$ & & $\begin{array}{l}\text { One } \\
\text { semester }\end{array}$ & $\begin{array}{l}\text { Participants' blog posts, } \\
\text { interviews, and ethnographic } \\
\text { papers }\end{array}$ \\
\hline
\end{tabular}




\begin{tabular}{|c|c|c|c|c|c|c|}
\hline Study & Purpose or Focus & $\begin{array}{l}\text { Theoretical } \\
\text { Framework }\end{array}$ & $\begin{array}{l}\text { Participant } \\
\text { Number, Age } \\
\text { and/or Grade }\end{array}$ & $\begin{array}{l}\text { Participants' } \\
\text { Dominant } \\
\text { Language }\end{array}$ & $\begin{array}{l}\text { Duration of } \\
\text { the Study }\end{array}$ & $\begin{array}{l}\text { Research Method and/or } \\
\text { Data Sources }\end{array}$ \\
\hline & $\begin{array}{l}\text { process between } \\
\text { their learning from } \\
\text { coursework and from } \\
\text { their observations of } \\
\text { senior teachers }\end{array}$ & & & & & \\
\hline Shin (2014) & $\begin{array}{l}\text { A grade } 2 \text { ELL } \\
\text { student's use of } \\
\text { blogging for social } \\
\text { and academic } \\
\text { purposes, in learning } \\
\text { academic writing } \\
\text { genres at school }\end{array}$ & $\begin{array}{l}\text { Sociocultural } \\
\text { theories; learning } \\
\text { as appropriation }\end{array}$ & $\begin{array}{l}\text { An ELL student } \\
\text { called Jose }\end{array}$ & Spanish & $\begin{array}{l}\text { One } \\
\text { academic } \\
\text { year }\end{array}$ & $\begin{array}{l}\text { Ethnography; written texts, } \\
\text { blog postings, videotaped } \\
\text { classroom interactions, } \\
\text { informal conversations, } \\
\text { interviews, instructional } \\
\text { materials, and } \\
\text { school documents }\end{array}$ \\
\hline Shin (2016) & $\begin{array}{l}\text { An ELL teacher's } \\
\text { metalanguage of } \\
\text { genre and register } \\
\text { shaping the } \\
\text { curriculum and } \\
\text { teaching of writing } \\
\text { science reports }\end{array}$ & $\begin{array}{l}\text { Systemic } \\
\text { Functional } \\
\text { Linguistics- } \\
\text { informed genre } \\
\text { pedagogy }\end{array}$ & $\begin{array}{l}\text { Grade } 1 \text { teacher } \\
\text { called Ms. Hall; } \\
\text { a bilingual } \\
\text { student called } \\
\text { Sara }\end{array}$ & $\begin{array}{l}\text { Student - } \\
\text { Vietnamese; } \\
\text { Teacher- } \\
\text { English }\end{array}$ & & $\begin{array}{l}\text { Field notes, curricular } \\
\text { materials, Glogster postings, } \\
\text { informal } \\
\text { interviews/conversations, } \\
\text { student texts }\end{array}$ \\
\hline $\begin{array}{l}\text { Snow, Eslami } \\
\& \text { Park } \\
(2016)\end{array}$ & $\begin{array}{l}\text { Kindergarten } \\
\text { students' literacy- } \\
\text { enriched play and } \\
\text { their writing }\end{array}$ & $\begin{array}{l}\text { Literacy-enriched } \\
\text { play }\end{array}$ & $\begin{array}{l}\text { Three students } \\
\text { and one teacher }\end{array}$ & $\begin{array}{l}\text { Student- } \\
\text { Indonesian, } \\
\text { English and } \\
\text { Dutch; }\end{array}$ & & $\begin{array}{l}\text { Exploratory pilot study; } \\
\text { observations, photographs of } \\
\text { students' block structures } \\
\text { and writing samples, field }\end{array}$ \\
\hline
\end{tabular}




\begin{tabular}{|c|c|c|c|c|c|c|}
\hline Study & Purpose or Focus & $\begin{array}{l}\text { Theoretical } \\
\text { Framework }\end{array}$ & $\begin{array}{l}\text { Participant } \\
\text { Number, Age } \\
\text { and/or Grade }\end{array}$ & $\begin{array}{l}\text { Participants' } \\
\text { Dominant } \\
\text { Language }\end{array}$ & $\begin{array}{l}\text { Duration of } \\
\text { the Study }\end{array}$ & $\begin{array}{l}\text { Research Method and/or } \\
\text { Data Sources }\end{array}$ \\
\hline & $\begin{array}{l}\text { development and } \\
\text { writing behaviors }\end{array}$ & & & $\begin{array}{l}\text { Teacher- } \\
\text { English }\end{array}$ & & $\begin{array}{l}\text { notes, recorded participant } \\
\text { actions }\end{array}$ \\
\hline $\begin{array}{l}\text { Soltero- } \\
\text { Gonzalez, } \\
\text { Escamilla \& } \\
\text { Hopewell } \\
(2012)\end{array}$ & $\begin{array}{l}\text { The study applied a } \\
\text { holistic bilingual } \\
\text { approach to assess } \\
\text { emerging Spanish- } \\
\text { English bilingual } \\
\text { students' writing }\end{array}$ & $\begin{array}{l}\text { Holistic } \\
\text { bilingualism }\end{array}$ & $\begin{array}{l}36 \text { bilingual } \\
\text { teachers }\end{array}$ & $\begin{array}{l}\text { Spanish and } \\
\text { English }\end{array}$ & $\begin{array}{l}\text { Five-year } \\
\text { longitudinal }\end{array}$ & $\begin{array}{l}216 \text { writing samples by } \\
\text { students }\end{array}$ \\
\hline $\begin{array}{l}\text { Sparrow, } \\
\text { Butvilofsky \& } \\
\text { Escamilla } \\
(2012)\end{array}$ & $\begin{array}{l}\text { Behaviors of } \\
\text { bilingual children in } \\
\text { a paired (English and } \\
\text { Spanish) literacy } \\
\text { program }\end{array}$ & Biliteracy & $\begin{array}{l}25 \text { students; } \\
\text { grade one to } \\
\text { grade three } \\
\text { emerging } \\
\text { bilingual } \\
\text { children }\end{array}$ & $\begin{array}{l}\text { Spanish and } \\
\text { English }\end{array}$ & Three years & $\begin{array}{l}\text { Longitudinal; quantitative } \\
\text { and qualitative; } 25 \text { student } \\
\text { writing samples }\end{array}$ \\
\hline Wong (2016) & $\begin{array}{l}\text { The writing } \\
\text { experiences and } \\
\text { expectations of a } \\
\text { bilingual student }\end{array}$ & $\begin{array}{l}\text { Sociocultural } \\
\text { theories; language } \\
\text { and literacy } \\
\text { socialization } \\
\text { theories }\end{array}$ & $\begin{array}{l}\text { A fourth-grade } \\
\text { Spanish-English } \\
\text { bilingual student, } \\
\text { Lizette }\end{array}$ & Spanish & One year & $\begin{array}{l}\text { Case study; field notes, audio } \\
\text { recordings, student work, } \\
\text { instructional artifacts }\end{array}$ \\
\hline $\begin{array}{l}\text { Yaden \& Tsai } \\
(2012)\end{array}$ & $\begin{array}{l}\text { Bilingual English } \\
\text { and Chinese } \\
\text { kindergarteners } \\
\text { "figuring out" the }\end{array}$ & $\begin{array}{l}\text { Socio- } \\
\text { psychogenetic and } \\
\text { microgenetic } \\
\text { approaches (e.g., }\end{array}$ & $\begin{array}{l}11 \text { Chinese } \\
\text { American } \\
\text { children }\end{array}$ & $\begin{array}{l}\text { English and } \\
\text { Chinese }\end{array}$ & $\begin{array}{l}\text { Three } \\
\text { months }\end{array}$ & $\begin{array}{l}\text { Interviews; observations, } \\
\text { trial analysis; video; } 11 \text { tasks } \\
\text { each in English and Chinese }\end{array}$ \\
\hline
\end{tabular}




\begin{tabular}{|c|c|c|c|c|c|c|}
\hline Study & Purpose or Focus & $\begin{array}{l}\text { Theoretical } \\
\text { Framework }\end{array}$ & $\begin{array}{l}\text { Participant } \\
\text { Number, Age } \\
\text { and/or Grade }\end{array}$ & $\begin{array}{l}\text { Participants' } \\
\text { Dominant } \\
\text { Language }\end{array}$ & $\begin{array}{l}\text { Duration of } \\
\text { the Study }\end{array}$ & $\begin{array}{l}\text { Research Method and/or } \\
\text { Data Sources }\end{array}$ \\
\hline & $\begin{array}{l}\text { differences between } \\
\text { English and Chinese } \\
\text { writing systems }\end{array}$ & $\begin{array}{l}\text { Granott, 2002; } \\
\text { Siegler \& Crowley, } \\
\text { 1991) }\end{array}$ & & & & \\
\hline Yi (2010) & $\begin{array}{l}\text { Writing engagement } \\
\text { and writing } \\
\text { development through } \\
\text { in- and out-of-school } \\
\text { writing }\end{array}$ & & $\begin{array}{l}\text { A Korean } \\
\text { immigrant high } \\
\text { school student }\end{array}$ & Korean & Two years & $\begin{array}{l}\text { Ethnographic case study; } \\
\text { observation, field notes, } \\
\text { interviews, literacy checklist, } \\
\text { scribbles, notes, } \\
\text { autobiography, poems, } \\
\text { personal diary entry, online } \\
\text { chatting, samples of } \\
\text { academic writing }\end{array}$ \\
\hline Yi (2013) & $\begin{array}{l}\text { Pre-service teachers' } \\
\text { sense of } \\
\text { preparedness, } \\
\text { challenges and } \\
\text { negotiation of } \\
\text { teacher identity in } \\
\text { teaching L2 writing }\end{array}$ & & $\begin{array}{l}\text { Two pre-service } \\
\text { ESOL teachers }\end{array}$ & & & $\begin{array}{l}\text { Reflective exploration; } \\
\text { interviews, observations, } \\
\text { artifacts, assignments } \\
\text { completed for internship } \\
\text { course, exit portfolios }\end{array}$ \\
\hline $\begin{array}{l}\text { Zapata \& } \\
\text { Laman } \\
(2016)\end{array}$ & $\begin{array}{l}\text { The characteristics of } \\
\text { classroom cultures } \\
\text { that support } \\
\text { translingual writing }\end{array}$ & $\begin{array}{l}\text { Translingual } \\
\text { literacies }\end{array}$ & $\begin{array}{l}\text { One each of a } \\
\text { second, third, } \\
\text { and fourth grade } \\
\text { classrooms and } \\
\text { three of the }\end{array}$ & $\begin{array}{l}\text { One teacher } \\
\text { identified } \\
\text { Spanish and } \\
\text { English }\end{array}$ & $\begin{array}{l}90 \text { hours of } \\
\text { observable } \\
\text { data and } \\
\text { two-three } \\
\text { days/week } \\
\text { classroom } \\
\text { visits }\end{array}$ & $\begin{array}{l}\text { Ethnography; observations, } \\
\text { artifacts, interviews, video } \\
\text { and audio, writing samples }\end{array}$ \\
\hline
\end{tabular}




\begin{tabular}{|c|c|c|c|c|c|c|}
\hline Study & Purpose or Focus & $\begin{array}{l}\text { Theoretical } \\
\text { Framework }\end{array}$ & $\begin{array}{l}\text { Participant } \\
\text { Number, Age } \\
\text { and/or Grade }\end{array}$ & $\begin{array}{l}\text { Participants' } \\
\text { Dominant } \\
\text { Language }\end{array}$ & $\begin{array}{l}\text { Duration of } \\
\text { the Study }\end{array}$ & $\begin{array}{l}\text { Research Method and/or } \\
\text { Data Sources }\end{array}$ \\
\hline & & & $\begin{array}{l}\text { teachers of these } \\
\text { classes }\end{array}$ & & & \\
\hline
\end{tabular}

